\title{
CULTURALLY CONDITIONED VISUAL COMMUNICATION IN CREATIVE EXPRESSION
}

\author{
Ilona VALANTINAITE் (D) 1, * Živilè SEDEREVIČIŪTĖ-PAČIAUSKIENE் (DD ${ }^{2}$, \\ Viktorija ŽILINSKAITÉ-VYTÉ ${ }^{3}$ \\ ${ }^{1}$ Vilnius Gediminas Technical University, Faculty of Creative Industries, Department of Philosophy and \\ Cultural Studies, Traku str. 1, LT-01132, Vilnius, Lithuania \\ ${ }^{2,3}$ Vilnius Gediminas Technical University, Faculty of Creative Industries, Department of Creative \\ Communication, Traku str. 1, LT-01132, Vilnius, Lithuania
}

Received 2 November 2019; accepted 14 April 2020

\begin{abstract}
The human body and its consciousness interacts with a number of external and internal factors, including, among others, the surrounding environment, experienced emotions, those things seen, things that are possessed and touched, and affection that is experienced, all of which accumulates over time as personal experience. In the aforementioned process memory plays the most significant role and predetermines the extent to which an individual remembers (and perceives) their own experience, and how they identify and are conscious of their own self-esteem, etc. The aim of this research is to record an idea and its transformations by reference to its associations, implementation and interpretations. Thus, transformations require personal experience, memory, knowledge, verbal and nonverbal abilities, as well as psychical phenomena that occur during research through the interaction of the participants. In our research task we presented 5 squares in which fragments of abstract pictures were placed. The participants were asked to freely interpret the fragments and complete the pictures. The results allowed us to conclude that associations and the process(es) of interpretation are inconstant and independent of each other. Associations usually visualise views of our physical environment, whereas intellectual creations are most frequently found in interpretations.
\end{abstract}

Keywords: visual communication, associations, creativity, divergent thinking, interpretations.

\section{Introduction}

For more than 60 years, creativity as a concept and its relevance to the creative capacity of individuals (Puryear, Kettler, \& Rinn, 2017) has been the subject of considerable research (Guilford, 1950; New World Encyclopedia, 2018). Human creativity is related to divergent (imaginative) thinking (Basadur \& Hausdorf, 1996; Sun, Wang, \& Wegerif, 2019), yet it is considered to be one of the most elusive of human abilities (Zmigrod, Colzato, \& Hommel, 2015). Divergent thinking is the propensity for the mind to generate ideas and find solutions

*Corresponding author. E-mail: ilona.valantinaite@vgtu.lt 
to problems outside normally prescribed expectations (Leclerc, 2017). Seen in this light, thinking itself is often contrasted with convergent thinking which is defined as a deductive process whereby rules are applied to arrive at a single, optimal solution. Divergent thinking is assumed to initially generate a broad range of solutions, whereas convergent thinking discerns which solutions are the most appropriate in order to arrive at the best possible solution (Furley \& Memmert, 2015). Certain parameters such as fluency, flexibility, originality, and elaboration are used to measure this ability (Torrance, 1974, 1995; New World Encyclopedia, 2018; Runco, 2008).

The literature holds that divergent thinking relies on cognitive processes such as "the retrieval of existing knowledge from memory, and the combination of various aspects of existing knowledge into novel ideas" (Paulus \& Brown, 2007, p. 252; also see Mednick, 1962). In utilizing the stockpiled knowledge that helps to form creativity, our working memory plays an important role. According to Guilford (1950) five operations come into play, comprising cognition, memory, convergent behaviour, divergent thinking and evaluation. Research has demonstrated that these abilities can be improved by cognitive stimulation, mood, and meditation (Zmigrod et al., 2015). Thus, memory is highly significant because it determines the extent to which an individual remembers, and perceives the self, as well as that individual's experience. Also important in this regard is the individual's exposure to a certain culture, i.e. experienced emotions, seen views, possessed and touched things, experienced affection for the surrounding, all of which builds personal experience. It is widely believed that an individual is first able to remember when they begin to acquire language, although strong emotional experiences are formed even earlier. However, memories from the pre-adolescent period may be false or deliberately formed (Vygotsky, 1979; Piaget \& Inhelder, 1996; Piaget, 2001). One's childhood memories are influenced by cultural environment, stories of family members, emotions and the fertile imagination of the individual. According to Adler (2011, 2014), childhood memories are never pure, but transformed, and indulged in fantasies or even myths, yet they are of great significance because the person's identity is built upon them, and it is well to remember that the risk of false memories may continue throughout a person's life. Emotions shared in common with others are vitally important for most people, but can easily change according to the particular moments that are remembered. Some individuals may be susceptible to the latter because they change due to external influence, whilst others want to simply fit in. There are people who doubt their own abilities or are influenced by additional factors (Loftus \& Pickrell, 1995; Loftus, 1997). Sleep deprivation has a negative impact on memory because reality is only vaguely perceived (Frenda et al., 2014) which may affect easier to influence some people by adjusting their memories. Misleading or partially false information will engender even more susceptibilities, especially if accompanied by visual aids. For example, the media exerts a powerful influence and can easily shape or change public opinion (Green et al. 2016; Crozier, Strange, \& Loftus, 2017). Further, real or false recollections of life events can be enhanced by the attendant emotions; experiencing visual stimuli with increased emotion tend to result in views that become an integral part of memory (Davachi \& Wagner, 2002; Davachi, Mitchell, \& Wagner, 2003; Crozier et al., 2017). Davachi (2004) came to the conclusion that neutral views seen after an emotionally charged event are memorised best, so that what our memory retains is directly dependent on our 
current emotional state. When mood is optimistic past events do not look so threatening, and vice versa. When we share memories we can expect some invented details to be added. In short, they become reliable and are transferred to memory.

Meanwhile, nonverbal experience is most frequently related to procedural memory. Procedures learned become not only remembrances or abilities but also skills that we do not take into account such that behaviour becomes automatic. Hence, we ride a bike, lace up shoes, wind a mechanical clock or make gingerbread biscuits for Christmas, and perform other activities without having to think about them. Remembrance of procedural memory is at the subconscious level, which might be why an individual may find it difficult to explain their specific behaviour. Yet, there are as many forms of memory as there are ways of perceiving, and every one of them is worth drawing upon for inspiration. Memory encompasses every facet of experience that we access from our cranial "hard drives", and it is this ability that allows us to store vital, yet seemingly trivial data, images and experiences of our lives (Tharp \& Reiter, 2006). In fact, the diversity of the individual's activities enriches and expands horizons, simultaneously increasing personal experience. Quite apart from this, the meta-analysis conducted by Kuykendall, Tay, and $\mathrm{Ng}$ (2015) revealed the relationship between leisure activities and subjective well-being, and well-being is one of the main conditions for the expression of creativity. In this respect, a variety of leisure areas increases successful life chances, and it is leisure activity that positively affects psychical and physical human health (Diener et al., 2017). Also, a proactive lifestyle is necessary if the brain is to perform its proper functions (Spartano et al., 2016). Seligman and Csikszentmihalyi (2000) described the benefits of active leisure and its link to enhanced satisfaction, especially when the activity itself causes the individual to lose track of time. Perhaps this is "luxury", i.e. when an individual pays greatest attention to the activity being conducted, and when all human powers are mobilised to perform activity that is seemingly effortless. In this way we experience the meaningfulness of daily life. Generalising, it can be stated that human experience, which directly depends on the individuality of a person (hobbies, inclinations, proactiveness, set goals, choices, morality, family, upbringing, etc.) is necessary for the expression of divergent thinking. Yet, to attain the accumulated experience not only certain circumstances but also human memory are required.

However, the awareness of different types of memory (and to be able to identify them) is not so important as to perceive the significance of memory and to make every attempt not to waste valuable experience. Tharp and Reiter (2006) points out that while developing creative expression, strengthening memory is of the utmost importance. In most cases, the human potential functions only due to memory. Therefore, in daily life it is difficult to decide which knowledge or experience(s) are vital and which can be disregarded. In certain situations of divergent thinking that are irrelevant this might be of importance. Generalising again, the cultural environment, family and peculiarities of life style in their broad sense play a significant role in the processes of creation and the transformation of personal remembrances.

Many scholars researching creativity argue that there is a close relationship between working memory and creativity (Gilhooly et al., 2007; Vartanian et al., 2013; Smeekens \& Kane, 2016). However, according to Smeekens' and Kane's experiment (2016) working memory capacity does not correlate with creativity in divergent thinking. They believe this 
is especially problematic for claims that so-called mind-wandering processes contribute to creative cognition. However, the question arises whether memory is relevant to all the forms of divergent thinking or just with specific forms of divergent thinking. Furley and Memmert (2015) investigated soccer-specific divergent thinking using the three criteria of fluency, flexibility, and originality and concluded that future research and theorizing on the role of working memory in everyday creative performance must distinguish between different types of creative performance, while also taking into account the role of domain-specific experience.

In exploring the nature of creativity one study (Beaty et al., 2017) argued that creativity cognition involves the ability to combine concepts stored in memory in order to generate novel associations. In the process of association, typical, usual, natural and best-known associations are provided first and they are the most numerous (Russ \& Dillon, 2011). First associations are typically not very original; original ideas are usually found only after the most obvious ideas are depleted (Mednick, 1962). Later knowledge, individual perception and general intelligence are employed in the process of transformation.

Süß et al. (2002), Oberauer et al. (2008) demonstrated that the capacity of our working memory was positively related to a series of different creativity tasks, which might include generating three-word sentences, or creating objects out of a fixed number of elements that observe certain rules of generation. Therefore, it is interesting to identify if there is any difference by country in the creation of objects out of a fixed number of elements on the basis of the hypothesis that informants from different countries are going to have different associations of their divergent thinking. The aim of the research is therefore to reveal differences in the processes of association and transformation of students from different countries through a series of creative tasks.

\section{Methods}

\subsection{Experimental design}

Creative nonverbal tasks are related to images - their perception, association, interpretation and visual thinking. Expressions of nonverbal creativity cannot be identified by reference to artistic expression or drawing skills alone, because even underdeveloped drawing skills allow us to create visual ideas. The interaction between a human body and the surrounding environment results in cognitive, volitional and emotional phenomena and processes, so that the idea and its transformations (associations, implementation and interpretations) are represented in the creative task. The expression of these transformations requires personal experience, memory, knowledge, verbal and nonverbal abilities, as well as the interactions of psychical phenomena that occur during the research (Russ \& Dillon, 2011).

The creative task for this research was designed following recommendations for creativity analysis suggested by Guilford (1968; also see New World Encyclopedia, 2018) and Torrance (1974, 1995). The Torrance Tests of Creative Thinking (TTCT) figural test was developed by Torrance in 1966 to measure creative potential. The tests have been continuously revised and administered with different populations. Several studies (Clapham, 2004; Cramond et al., 2005; Cropley, 2000; Kim, 2006, 2011) have confirmed the validity of TTCT in assessing multidimensional creativity. The TTCT were specifically designed to gauge the divergent aspects of creativity in two different areas of testing - verbal and figural. 
In the TTCT, participants were asked to sketch and explain different objects in response to visual stimuli presented in the test within the restricted time limits. The task included 5 squares with fragments of abstract fragments of drawing (e.g., circles, lines, abstract drawings) (Figure 1).

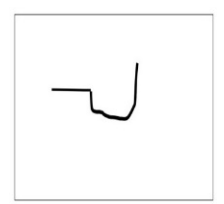

Fragment 1

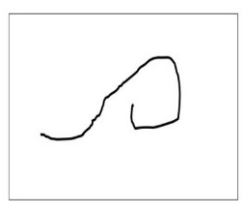

Fragment 2

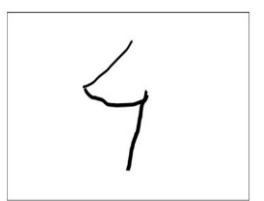

Fragment 3

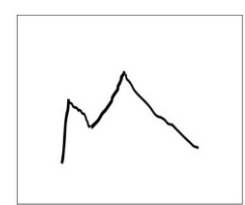

Fragment 4

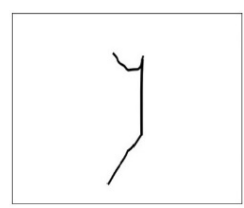

Fragment 5

Figure 1. The creative tasks: Fragments 1 to 5 (source: testingmom.com, 2020)

Before commencing, the participants were given a full explanation of what they were expected to do. The three stages of task were presented: stage 1 - write down the association a student makes while seeing a fragment of drawing in the square; stage 2 - complete the fragment in the square using colours and the given fragment as the construction of the new drawing; stage 3 -write down the title of the finished drawing (Figure 2).
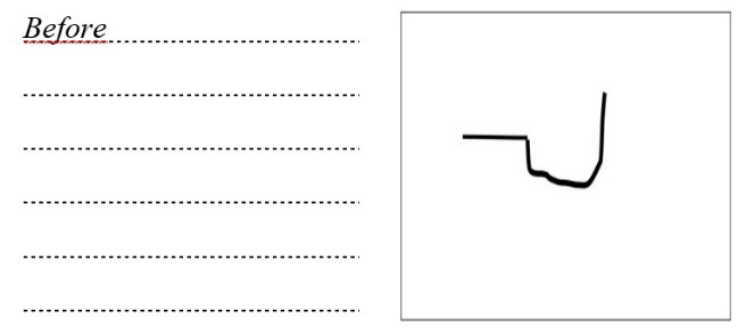

After

Figure 2. Presentation of a three-stage creative task (source: testingmom.com, 2020)

The first stage of the creative task is related to the process of association, whereas the second and the third stages involve interpretation. The process of association is considered to be the relationship of separate consciousness images. The process of interpretation is seen as revelation and presentation of one's own peculiar understanding, interpretation of meaning and its commenting as well as individual actualisation. The first and the third stages focused on verbal expression about visual content and showed verbal associations and interpretations of visual works. The second stage targeted at visual expression showed the further development of abstract visual works.

Participants were given pencils of 12 different colours and allowed to choose the colours they preferred. The time allocated for completion of the task was 13 minutes.

Analysis of the completed creative task focused on the idea recorded by the research participant and its transformations, such as association, implementation and interpretation.

\section{Participants}

The research sample comprised 115 students studying in six universities in 5 countries: Lithuania $(16.5 \%, \mathrm{n}=19)$, Latvia $(27.0 \%, \mathrm{n}=31)$, Estonia $(13.0 \%, \mathrm{n}=15)$, Belarus $(27.0 \%, \mathrm{n}=31)$ and Slovenia $(16.5 \%, \mathrm{n}=19)$. The age of research participants ranged from 16 to 51 years. At 
the time of the research the students were enrolled in full-time and part-time bachelor studies (Lithuania, Latvia, Estonia, Belarus and Slovenia). The study programmes of the students in the research were targeted at the training of teachers studying a particular subject and a similar curriculum. All of the students were learning handcrafts, grounded in the national heritage and the country's traditions. The expression of creativity was one of the key goals and requirements in the study programmes of participants. The distribution of students according to years of studies was as follows: $13.0 \%(n=15)$ were 1 st year students, $26.1 \%(n=30)-2$ nd year students, $23.5 \%(n=27)-3$ rd year students, $31.3 \%(n=36)-4$ th year students and $6.1 \%(n=7)$ of the participants were 5 th year students.

\section{Results}

The locality and cultural universality of associations and interpretations evoked by images manifested themselves at all stages of the research. This would suggest that an abstract line or a curve should not associate with different object or phenomena for people from a western culture who are likely to share an understanding of the history and tendencies of western art. In particular, the study took into account that the research sample consisted of students from the same group of study fields, i.e. educational sciences. Nevertheless, the analysis of associations and interpretations revealed that in relation to the visual content, local culture is significant and results in different perceptions of the content.

The associations evoked by an abstract line and their interpretation discloses not only the importance of differences in visual culture, but also the peculiarities of worldview-based cultural aspects. Hence, an abstract line was more frequently associated with a working tool in traditionally Protestant countries compared to other historical religious territories. The landscape and landscape-related cultural relation with a specific horizontal line, as well as the cultural significance of landscape in the perception of one's own identity, explicitly encourages us to see peculiarities of our own cultural environment in the abstract lines found in different landscapes and its cultural interpretations only in rare cases.

The relationship between associations evoked by abstract drawings and their interpretations indicate the lack of reflection in the process of communication. If we take a different position in the act of communication, i.e. association while receiving the message and interpretation (both visual and verbal) while understanding the message, this would draw attention to the lack of reflection. In short, the evoked associations are rarely developed and interpretations of abstract drawings are not continued further but divert to new images.

\section{Analysis of creative task: Fragment 1}

Earth surface deformations and working tools prevailed among associations of the first abstract drawing. In the drawing extension and its interpretation, the theme of landscape appeared more often, whereas that of tools was less frequent. Interestingly, working tools in the association stage were replaced by kitchenware and tableware in the interpretation stage.

In the process of association almost one third of students (30.4\%) linked the fragment presented in the drawing with surface deformations: "a pit", "a cavity", "a failure" and others. And with the help of coloured pencils in the process of interpreting the provided fragment the deformations turned into a broader view, i.e. landscape (Tables 1, 2). 


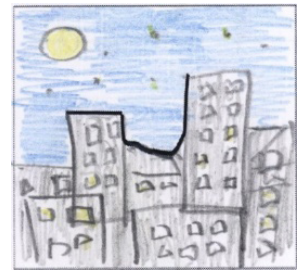

A city

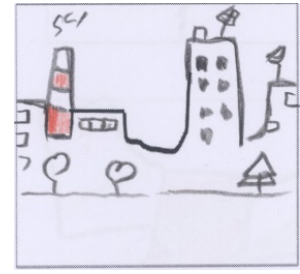

A city

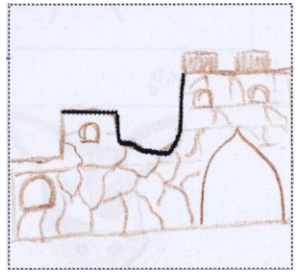

The ruins of castle

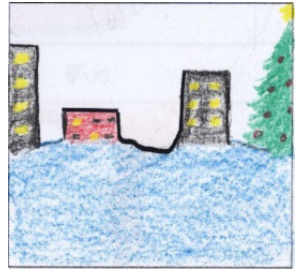

A city covered in snow

Figure 3. The creative task: interpretation of Fragment 1 - city views (source: testingmom.com, 2020)

The interpreted images assigned to the group of landscapes can be divided into two groups -city ("a town", "a district of skyscrapers", "buildings in the distance", "housing estates" and others) (Figure 3) and nature ("a river bend beside the town", "a river bed", "two waterfalls", "a beach and a lake" and others) views (Figure 4).

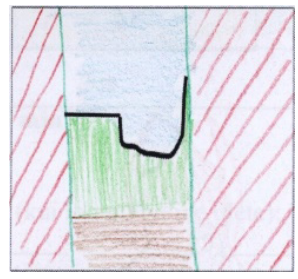

View through window: the landscape

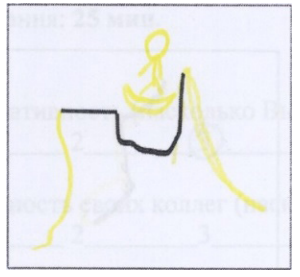

An ice slide (a hill)

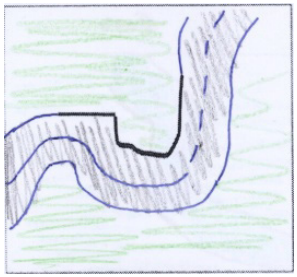

A road

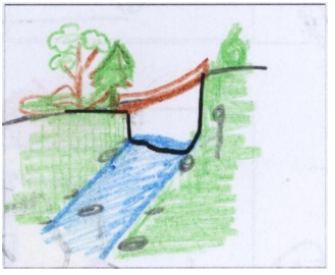

A river bed

Figure 4. The creative task: interpretation of Fragment 1 - nature views

(source: testingmom.com, 2020)

The convergence of media content as a result of globalisation suggests a similar perception of visual content. However, visual differences in the immediate environment that exist among countries predetermine interpretations of visual abstractions. The analysis revealed that the participants from Estonia did not envisage any surface deformations in the process of association, however one third of Estonian students drew landscape while interpreting the given fragment (Tables 1, 2).

Table 1. Associations of Fragment 1 (\%) (source: created by authors)

\begin{tabular}{|l|c|c|c|c|c|c|}
\hline & In total & Lithuania & Latvia & Estonia & Slovenia & Belarus \\
\hline \multicolumn{7}{|c|}{ Most frequent associations } \\
\hline $\begin{array}{l}\text { Deformation of Earth } \\
\text { surface }\end{array}$ & 30.4 & 57.9 & 16.1 & 0 & 52.6 & 29.0 \\
\hline Work tools & 13.9 & 15.8 & 6.5 & 26.7 & 5.3 & 22.6 \\
\hline Mathematic element & 7.0 & 10.5 & 6.5 & 6.7 & 5.3 & 9.7 \\
\hline \multicolumn{7}{|c|}{ Least frequent associations } \\
\hline Philosophy & 0.9 & 0 & 3.2 & 0 & 0 & 0 \\
\hline Animals & 0.9 & 0 & 3.2 & 0 & 0 & 0 \\
\hline Cardiogram & 0.9 & 0 & 0 & 0 & 0 & 3.2 \\
\hline
\end{tabular}


Table 2. Interpretations of Fragment 1 (\%) (source: created by authors)

\begin{tabular}{|l|c|c|c|c|c|c|}
\hline & In total & Lithuania & Latvia & Estonia & Slovenia & Belarus \\
\hline \multicolumn{7}{|c|}{ Most frequent interpretations } \\
\hline Landscape & 26.1 & 21.1 & 12.9 & 33.3 & 31.6 & 29.0 \\
\hline Place, territory, its marking & 10.4 & 15.8 & 19.4 & 6.7 & 10.5 & 3.2 \\
\hline Tableware, kitchenware & 8.7 & 10.5 & 9.7 & 0 & 5.3 & 12.9 \\
\hline \multicolumn{7}{|c|}{ Least frequent interpretations } \\
\hline Violence & 0.9 & 0 & 0 & 0 & 0 & 3.2 \\
\hline $\begin{array}{l}\text { Mathematical, physical } \\
\text { element }\end{array}$ & 0.9 & 5.3 & 0 & 0 & 0 & 0 \\
\hline Script, signs & 0.9 & 0 & 3.2 & 0 & 0 & 0 \\
\hline A character & 0.9 & 0 & 0 & 0 & 0 & 3.2 \\
\hline Food & 0.9 & 5.3 & 0 & 0 & 0 & 0 \\
\hline
\end{tabular}

A number of drawings depicting earth surface deformations were interpreted through activities. Several interpretations of nature views, which also depict the place that is suitable for human activities, should be distinguished: "a springboard for water jumps" and "an icy hill for going down on a sledge", "sledging on ice" (Figure 4). Some more interpretations of Fragment 1 included images of people's activities: "a scarp" and "the boy jumping into the water" (Figure 5). All the images related to people's activities were submitted by the participants from Belarus.

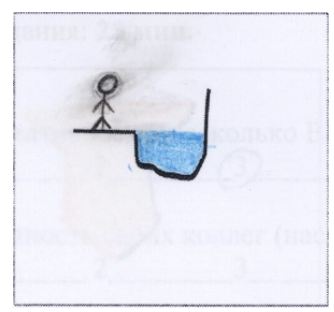

A boy jumping into the water

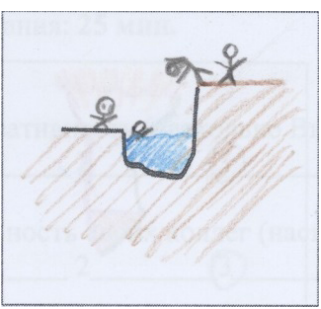

A scarp

Picture 5. The creative task: interpretation of Fragment 1 - people's activities (source: testingmom.com, 2020)

As mentioned previously, the working tools in the process of association were replaced by tableware while interpreting the given fragment. Although the number of references to tableware in interpretations exceeded that in associations, the total number of occurrences of tools and ware (working, table and kitchen) decreased. About $4.3 \%$ of participants associated Fragment 1 in the creative task with kitchen and tableware, whereas more of them (8.7\%) did the same in the process of interpretation (Tables 1,2). The kitchenware and dishes associated and interpreted by the students in the research are quite common in any kitchen: "a ladle", "a sieve", "a dish", "a kettle", "an old ladle" and others (Figure 6). Therefore, it is possible to state that the everyday environment influences the processes of both association and interpretation. 


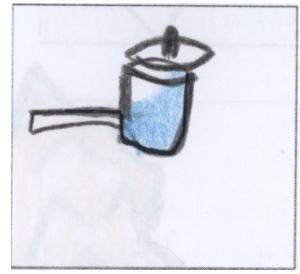

A kettle

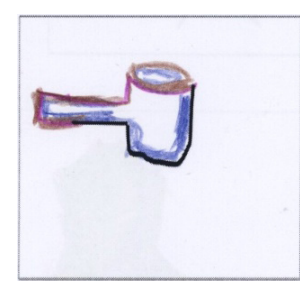

An old ladle

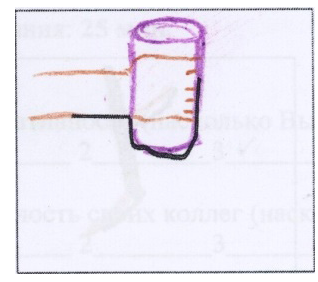

A glass in hand

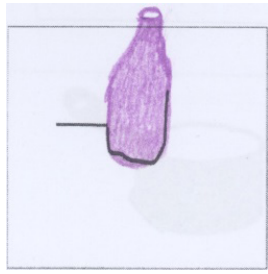

A bottle

Figure 6. The creative task: interpretation of Fragment 1 - kitchenware and dishes (source: testingmom.com, 2020)

Three research participants provided exceptional associated images and five exceptional images were presented while interpreting the fragment. The students from Lithuania interpreted Fragment 1 as "a candy" and "a curve", the students from Latvia drew a punctuation mark ("a question mark", and the participants from Belarus - a character - "a witch" and a violent scene - "a murder" (Figure 7).

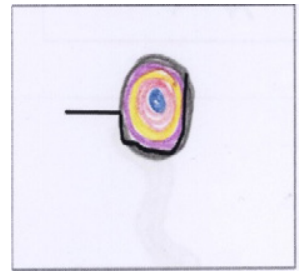

A candy

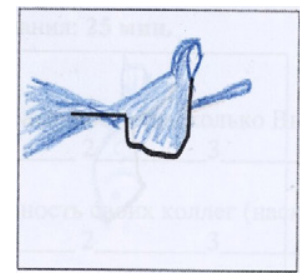

A witch

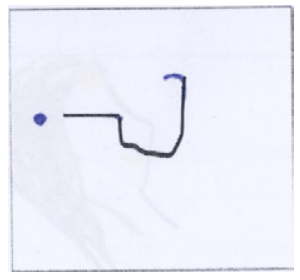

A question mark

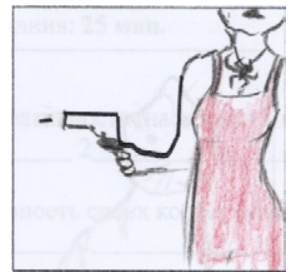

A murder

Figure 7. The creative task: interpretation of Fragment 1 - exceptional images (source: testingmom.com, 2020)

The drawing of a witch allows us to assert that the process of interpretation can be predetermined not only by physical environment but also by the already viewed, or currently read, books or animation films. The witch is one of the most familiar characters in Russian fairy-tales. In order to reveal a broader effect of fairy-tale characters on the individual's creativity, further research is needed, although the impact of a particular cultural environment is highly relevant.

\section{Analysis of creative task: Fragment 2}

The interpretations and associations of Fragment 2 referred to animals, nature and the mathematical symbol for infinity. The motif of animals in interpretation increased, whereas the frequency of references to abstract nature (without specification) and mathematical symbols showed a downward tendency. The stability in perception of soft forms in visual communication discloses the universality of the symbol and archetypicality of natural elements in perception.

Only one fourth (24.3\%) of research participants related Fragment 2 of the creative task to animals in the process of association, and in the process of interpretation such reference was characteristic of almost twice as the large number of participants $(41.7 \%)$ (Tables 3, 4). The presented fragment was associated with animals by almost one third of students from 
Lithuania and Slovenia. In the process of the interpretation the frequency of the abovementioned link rose in the creative tasks of participants from all the countries, although the biggest rise was among Belarusian (a fourfold increase) and Lithuanian (a twofold increase) students (Tables 3, 4).

Table 3. Associations of Fragment 2 (\%) (source: created by authors)

\begin{tabular}{|l|c|c|c|c|c|c|}
\hline & In total & Lithuania & Latvia & Estonia & Slovenia & Belarus \\
\hline \multicolumn{7}{|c|}{ Most frequent associations } \\
\hline Animals, parts of their bodies & 24.3 & 31.6 & 25.8 & 26.7 & 31.6 & 12.9 \\
\hline Mathematic elements & 13.0 & 15.8 & 6.5 & 0 & 15.8 & 22.6 \\
\hline Nature & 12.2 & 21.1 & 16.1 & 6.7 & 10.5 & 6.5 \\
\hline Tools & 12.2 & 10.5 & 12.9 & 20.0 & 0 & 16.1 \\
\hline \multicolumn{7}{|c|}{ Least frequent associations } \\
\hline Plants & 0.9 & 0 & 3.2 & 0 & 0 & 0 \\
\hline Celestial bodies & 0.9 & 5.3 & 0 & 0 & 0 & 0 \\
\hline
\end{tabular}

Table 4. Interpretations of Fragment 2 (\%) (source: created by authors)

\begin{tabular}{|l|c|c|c|c|c|c|}
\hline & In total & Lithuania & Latvia & Estonia & Slovenia & Belarus \\
\hline \multicolumn{7}{|c|}{ Most frequent interpretations } \\
\hline Animals, their elements & 41.7 & 57.9 & 35.5 & 26.7 & 42.1 & 45.2 \\
\hline Nature & 8.7 & 5.3 & 3.2 & 20.0 & 10.5 & 9.7 \\
\hline Shoes, their elements & 8.7 & 5.3 & 16.1 & 6.7 & 0 & 9.7 \\
\hline Mathematic element & 6.1 & 0 & 3.2 & 0 & 5.3 & 16.1 \\
\hline \multicolumn{7}{|c|}{ Least frequent associations } \\
\hline Human and body parts & 0.9 & 5.3 & 0 & 0 & 0 & 0 \\
\hline Rack & 0.9 & 0 & 0 & 6.7 & 0 & 0 \\
\hline Food & 0.9 & 0 & 0 & 0 & 5.3 & 0 \\
\hline
\end{tabular}

Snails comprised almost half of the cases (48\% (23 out of 48)) of interpreted animals (Figure 8). They were mentioned in the interpretations of 37\% Lithuanian, 26\% Slovenian, 19\% Latvian, 13\% Estonian and 10\% of Belarusian participants. The students from Lithuania, Latvia and Slovenia personalised their snails adding smiles or calling their interpretations "a smiling snail" or "a blue snail".

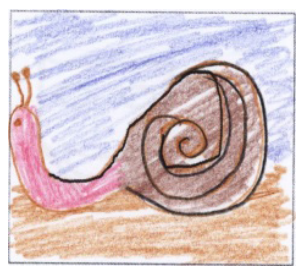

A snail

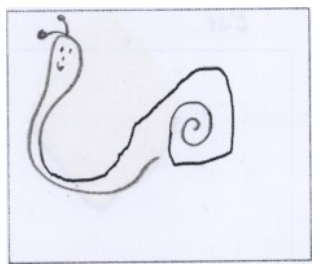

A snail

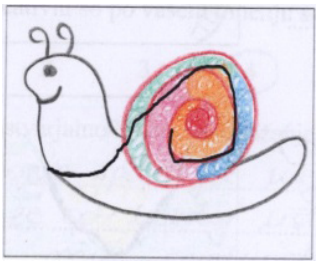

A nice, colourful snail

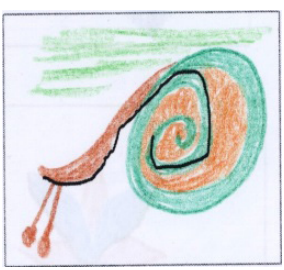

A snail upside down

Figure 8. The creative task: interpretation of Fragment 2 - animals: snail

(source: testingmom.com, 2020) 
Snakes make up 17\% (8 out of 48 ) of all the interpreted animals (in creative interpretations of Belarusian (13\%), Latvian (10\%) and Slovenian (5\%) participants). A cobra (Belarus) and a worm (Lithuania) were mentioned once and two students (Estonia and Lithuania) made reference to earthworms (Figure 9).

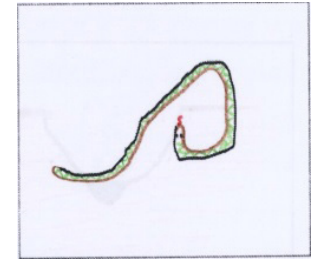

A snake

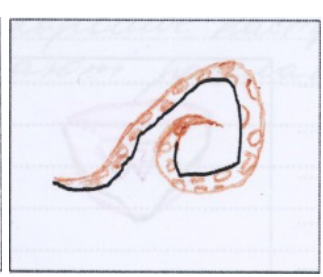

A cobra

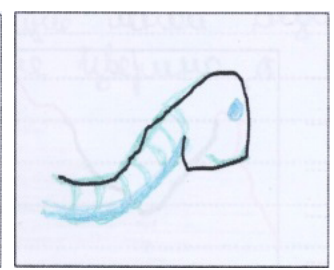

A worm

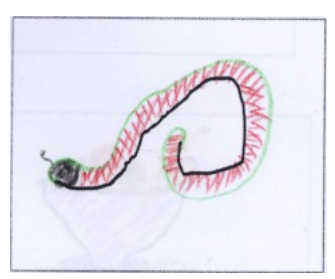

A poor rain earthworm

Figure 9. The creative task: interpretation of Fragment 2 - animals: crawling creatures (source: testingmom.com, 2020)

Creatures that remind us of several kinds of animals made up about one fifth of interpretations (17\% or 8 out 48 ): a butterfly was mentioned twice (Lithuania, Latvia) as well as an elephant (Latvia, Belarus), a unicellular organism (Slovenia), a horse (Belarus), a black cat (Lithuania) and "a mysterious animal" (Estonia) were mentioned once (Figure 10).

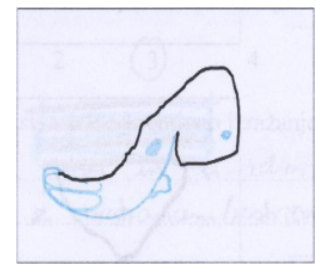

A unicellular organism

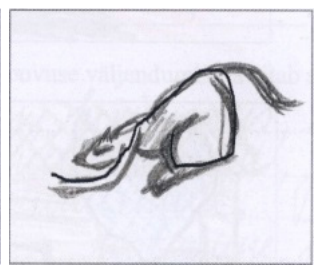

A mysterious animal

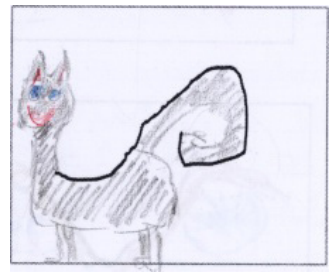

A black cat

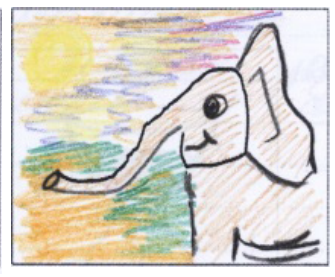

An elephant in the sunrise

Figure 10. The creative task: interpretation of Fragment 2 - the variety of animals (source: testingmom.com, 2020)

All the above-described animals (with the exception of elephants) are present in the physical environment of participants almost every day. It follows that the interpreted animals provoke participants into using certain forms of living nature or a specific object, however let us consider the above-mentioned elephants which now can be seen at the zoo, at the circus, on television, and in pictures, etc. Today, an elephant is familiar to most people. Of particular interest is one participant who refers to a unicellular organism which is present in the natural environment but can only be seen by means of a microscope. Yet, the images of unicellular organisms are depicted in school textbooks, reference books or on specialised posters. Such an image is assigned to the impact on the expression of creativity, i.e. on the process of associations and interpretations, produced by intellectual products (posters, pictures, etc.).

About 10\% (5 out 48 ) of interpreted animals were dinosaurs, and were referred to in two creative assignments presented by participants from Slovenia and Belarus and once by a Lithuanian (Figure 11). The Latvian and Estonian participants did not associate this fragment with dinosaurs. Dinosaurs are historical animals, however their images today are 
encountered in textbooks or specialised books, and in the virtual space, playgrounds, parks and elsewhere. With the help of intellectual products, the availability of these images enable people to accumulate a broad diversity of images and, thus, create favourable conditions for creative processes.

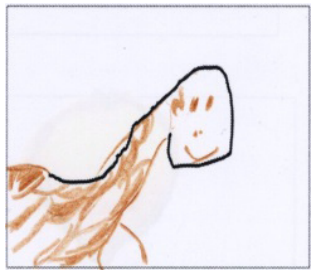

The head of dinosaur

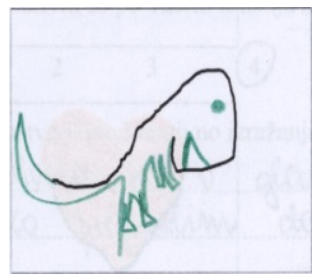

A dinosaur

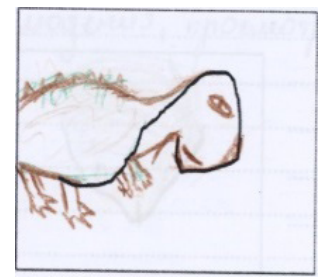

A dinosaur

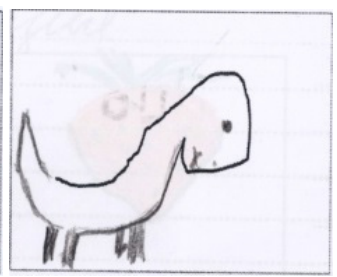

A dinosaur

Figure 11. The creative task: interpretation of Fragment 2 - animals: dinosaurs (source: testingmom.com, 2020)

The interpretation of the presented fragment employing the animal motif indicates the influence of animated nature on the personal processes of association and interpretation. The analysis of the research data revealed that the participants tended to more frequently link the presented fragment to a specific animated or inanimate object in the processes of association as well as interpretation. Representation of the whole is not frequent in the creative tasks performed. Despite the above-mentioned, the interpreted images of Fragment 2 assigned to a group of nature, contained an image of a beach called "waves in the sea" by a third-year Lithuanian student. The interpretations of other students were related to specific objects such as a lake, a wave, a rock, etc. (Figure 12). The participants from Estonia and Belarus transformed the presented fragment into popular outside activities in nature, e.g. winter sports: tobogganing and snowboarding (Figure 12). It can be said that the process of interpretation is preconditioned not only by physical environment, but also by personal occupations, activities and environments.

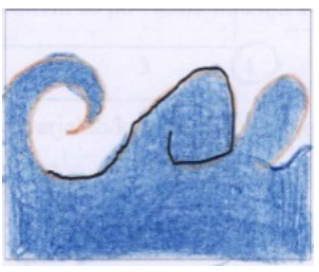

Sea waves: interesting how they travel

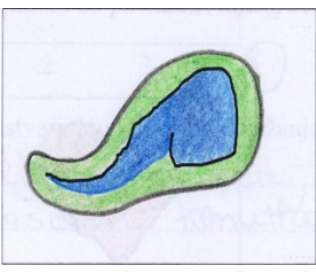

A lake surrounded by a green path as if by smoke

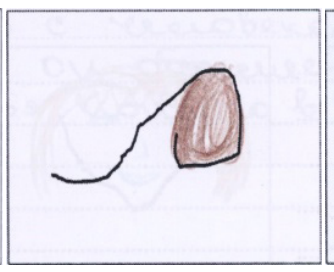

A rock

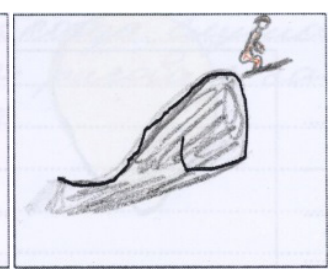

A mountain for a snowboarder

Figure 12. The creative task: interpretation of Fragment 2 - nature (source: testingmom.com, 2020)

Fragment 2 in the creative task was associated with tools by $12.2 \%$ of the research participants (Figure 13), and as many as one fifth of them $(20.0 \%)$ were from Estonia. In the process of interpretation only two students linked the fragment with tools; none of them were from Estonia (Tables 3, 4). 


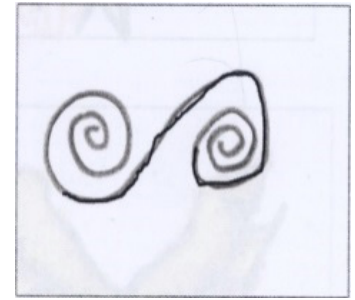

A spiral

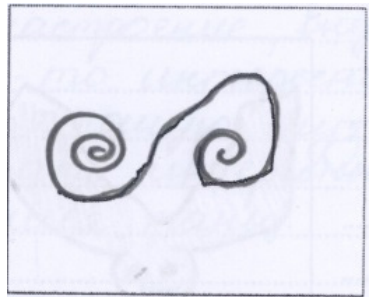

A hook

Figure 13. The creative task: interpretation of Fragment 2 - tools (source: testingmom.com, 2020)

The associations of Fragment 2 with shoes were presented by $3.5 \%$ of the research participants, whereas the frequency of this link went up to $8.7 \%$ in the process of interpretation. The Latvian students provided the biggest number of associations and interpretations using the motif of shoes (Table 4). While interpreting the fragment, most frequently shoes had a heel, although sneakers, clown shoes or a joker's shoe were also provided by the participants (Figure 14).

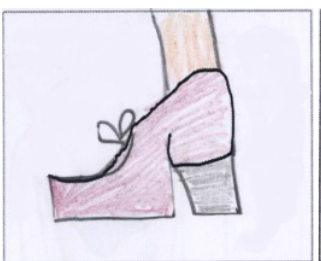

One trendy shoe

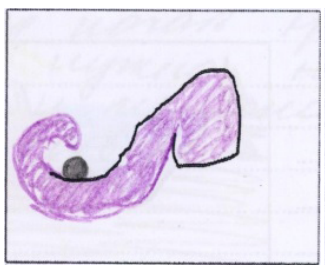

Shoes

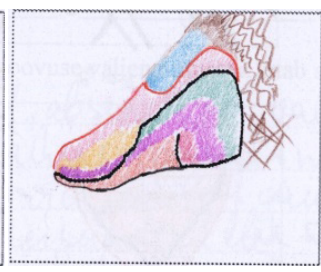

A sneaker

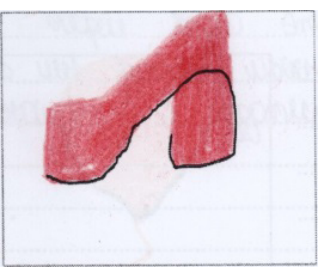

A shoe on platform

Figure 14. The creative task: interpretation of Fragment 2 - footwear (source: testingmom.com, 2020)

Some participants (13.0\%) associated the presented fragment with a symbol of infinity assigned to mathematical elements (Figure 15), although this symbol was used in just $6.1 \%$ of interpretations. The above-mentioned element was used in interpretations of one sixth of Belarusian participants, however such interpretation was not chosen by those from Lithuania and Estonia (Tables 3, 4).

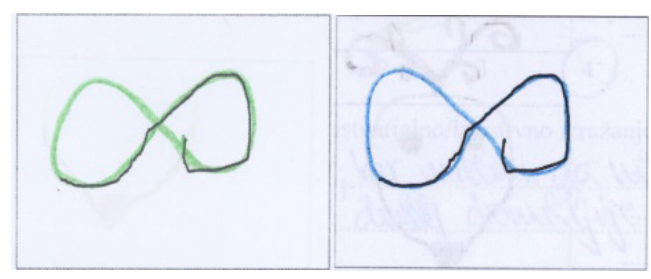

An infinity symbol

An infinity symbol

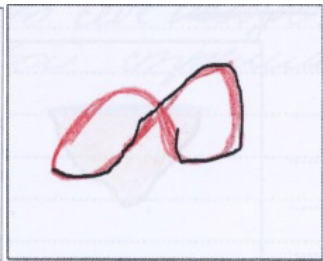

Infinity

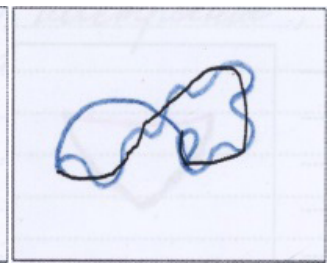

8

Figure 15. The creative task: interpretation of Fragment 2 - a symbol of infinity (source: testingmom.com, 2020) 
One participant from Estonia, Slovenia and Lithuania presented an exceptional interpretation for each (a flower holder, an ice-cream, a heart) of Fragment 2 in the creative task (Figure 16).

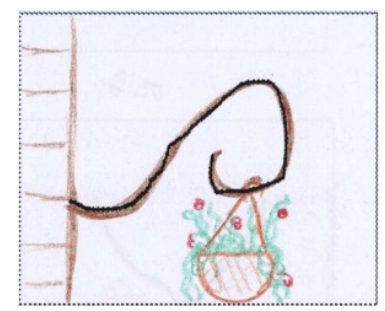

Flower holders

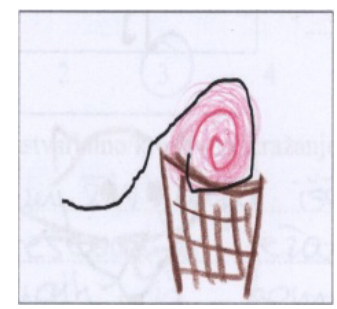

Food

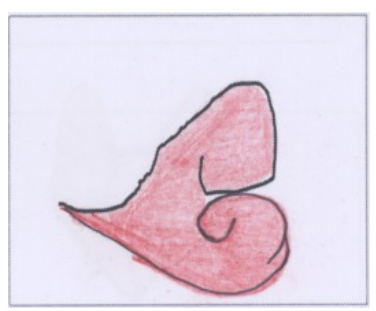

A human being

Figure 16. The creative task: interpretation of Fragment 2 - exceptional images (source: testingmom.com, 2020)

The exceptional images in the process of interpretation presented by Latvian and Lithuanian participants were assigned to groups of plants and celestial bodies. Interpretations on the motif of plants rose to $2.6 \%$, and a group of celestial bodies was not identified at all in this stage.

\section{Analysis of creative task: Fragment 3}

Although more than half of the research participants associated Fragment 3 with number 4 , the most frequent interpretations were related to plants. The ambiguity of understanding mathematical signs and symbols is seen in the culture. The turning of such "self-evident" numbers into a sign has been known since the "Book of Numbers" of the Old Testament, which may have fostered the formation of Cabalism. In contemporary popular culture numbers become "more than numbers" in a long-running detective story. The television series Numbers (2005-2010, created by Nicolas Falacci and Cheryl Heuton) presents an exceptional concentration of numbers. The mystification of numbers is evidenced by the fact that mathematicians make up the majority among "mad scientists" in works of popular culture. The disposition to see hidden meaning was disclosed in the transition from the processes of association and interpretation. Having envisaged a number in abstraction, the research participants did not further develop this topic. Differently from the sign of infinity, which appeared in the communication of soft abstractions and was perceived not only in the context of mathematics but also in that of nature and universe, concrete numbers were found only among associations.

More than half of the research participants (52.2\%) associated Fragment 3 of the creative task with a mathematical element, i.e., number 4 . In the process of interpretation, the latter fragment was transformed into numbers only in the works of two participants (1.7\%): a four for a third-year student from Latvia and a nine for a second-year Belarusian student, who had previously envisaged a four (Figure 17). 


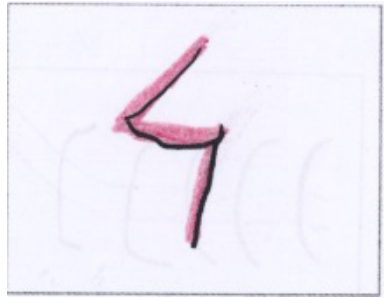

Four

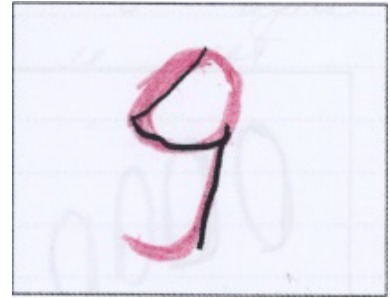

Number 9

Figure 17. The creative task: interpretation of Fragment 3 - numbers (source: testingmom.com, 2020)

One third (33.0\%) of the research participants associated the presented fragment with a human: a face, a body and a nose. The number of links of the discussed fragment with a human halved, i.e. equalled $16.5 \%$ in the process of interpretation (Figure 18).

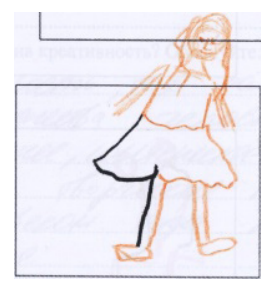

A girl

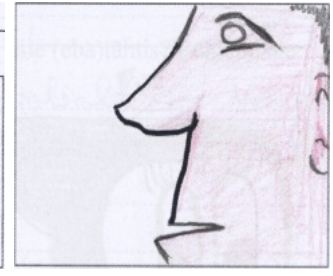

A profile

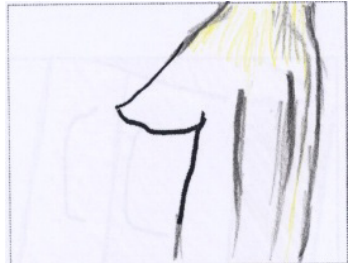

A female body, a nude woman

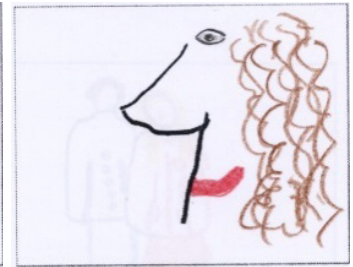

A person's profile with a very long nose

Figure 18. The creative task: interpretation of Fragment 3 - a human being (source: testingmom.com, 2020)

It was noticed that two fifths (40.0\%) of Estonian and almost three fourths $(73.7 \%)$ of Slovenian students linked the fragment with a human being in the processes of association and interpretation (Tables 5, 6).

Table 5. Associations of Fragment 3 (\%) (source: created by authors)

\begin{tabular}{|l|c|c|c|c|c|c|}
\hline & In total & Lithuania & Latvia & Estonia & Slovenia & Belarus \\
\hline \multicolumn{7}{|c|}{ Most frequent associations } \\
\hline Number & 52.2 & 68.4 & 45.2 & 53.3 & 15.8 & 71.0 \\
\hline Human, body parts & 33.0 & 26.3 & 29.0 & 40.0 & 73.7 & 12.9 \\
\hline Plant life & 5.2 & 0 & 9.7 & 6.7 & 0 & 6.5 \\
\hline \multicolumn{7}{|c|}{ Least frequent associations } \\
\hline Tools, their elements & 0.9 & 0 & 3.2 & 0 & 0 & 0 \\
\hline Umbrellas & 0.9 & 0 & 3.2 & 0 & 0 & 0 \\
\hline Games & 0.9 & 0 & 0 & 0 & 5.3 & 0 \\
\hline Animal life & 0.9 & 0 & 0 & 0 & 0 & 3.2 \\
\hline
\end{tabular}


Table 6. Interpretations of Fragment 3 (\%) (source: created by authors)

\begin{tabular}{|l|c|c|c|c|c|c|}
\hline & In total & Lithuania & Latvia & Estonia & Slovenia & Belarus \\
\hline \multicolumn{7}{|c|}{ Most frequent interpretations } \\
\hline Plant life & 34,8 & 31.6 & 45.2 & 26.7 & 36.8 & 29.0 \\
\hline Textile & 17.4 & 10.5 & 16.1 & 6.7 & 15.8 & 29.0 \\
\hline $\begin{array}{l}\text { Human, its body } \\
\text { parts }\end{array}$ & 16.5 & 15.8 & 12.9 & 40.0 & 26.3 & 3.2 \\
\hline \multicolumn{7}{|c|}{ Least frequent interpretations } \\
\hline Stationery & 0.9 & 0 & 0 & 0 & 0 & 3.2 \\
\hline Footwear & 0.9 & 5.3 & 0 & 0 & 0 & 0 \\
\hline Games & 0.9 & 0 & 0 & 0 & 0 & 3.2 \\
\hline Dishes, containers & 0.9 & 5.3 & 0 & 0 & 0 & 0 \\
\hline
\end{tabular}

A man's face was clearly present in two works. A 40-year old Estonian student drew a darker-skinned brown-eyed man's face with a beard and moustache. The use of face of the opposite sex maybe linked to the opposite sex but it does not have any correlation with the age, because the author of the second interpreted moustached face is a 21-year old student from Estonia. The interpretations of a nude female body were also two in number but they can be linked neither with the gender nor with the age. The authors of those interpretations are a 20-year old first-year Latvian student and a 41-year old final year student from the University of Tartu, Estonia. The majority of the authors of interpretations representing a human drew a female profile or a face of hardly identifiable sex. Several exclusive elements found in the works should be singled out: Slovenian student decorated the drawn face with a nose ring and a Belarusian student presented a female full-length figure in a dress and called it "a girl" (Figure 18).

Only $5.2 \%$ of the respondents associated Fragment 3 of the creative task with plants but the frequency of this link with plants in the process of interpretation had already risen to $34.8 \%$ (Figures 19, 20).

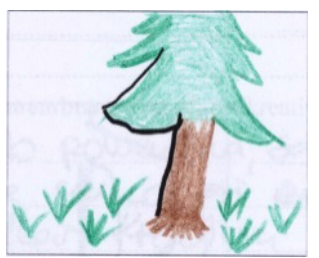

A fir-tree

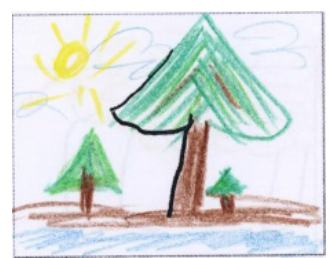

A fir-tree

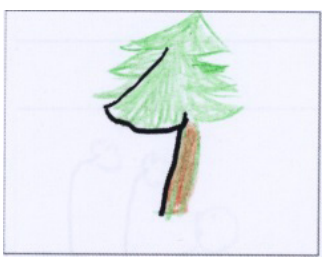

A fir-tree

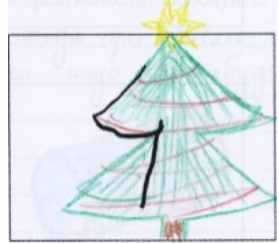

A fir-tree

Figure 19. The creative task: interpretation of Fragment 3 - plants: fir-trees (source: testingmom.com, 2020)

The interpretation on the plant theme can be divided into two parts: fir-trees (Figure 19) and mushrooms (Figure 20). The number of fir-trees in the pictures (26\%) is three times as big as that of mushrooms (9\%) and half of the latter are called a fly agaric, two mushrooms are referred to as boletus and the remaining ones comprise interpretations that bear no resemblance to the researchers' mushrooms (Figure 20). The greatest number of interpretations 
with mushrooms (6) were presented by Latvian students; Lithuanian and Belarusian participants provided two. No edible mushrooms or fly agarics were found among interpretations by Slovenian and Estonian students (Table 6).

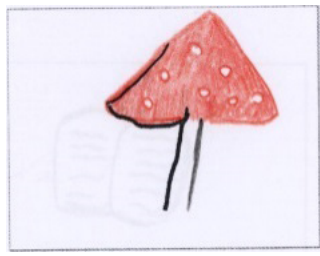

A fly agaric

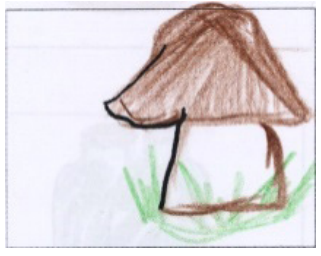

A mushroom

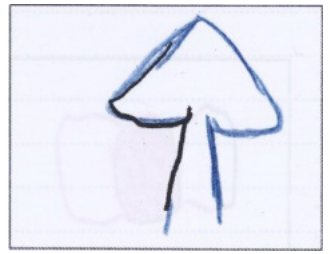

A mushroom

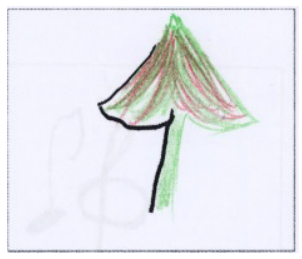

A mushroom

Figure 20. The creative task: interpretation of Fragment 3 - plants: mushrooms (source: testingmom.com, 2020)

Four Christmas trees were found among interpretations containing fir-trees: one student from Slovenia and Lithuania and two from Belarus interpreted Fragment 3 employing the image of a Christmas tree. Although $45.2 \%$ of Latvian and $26.7 \%$ of Estonian students used the motif of plant in their interpretations, none of them saw a Christmas tree in the fragment.

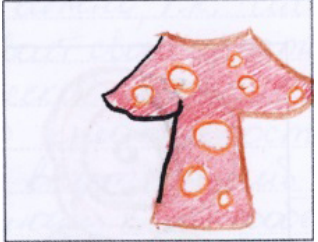

A dotted dress

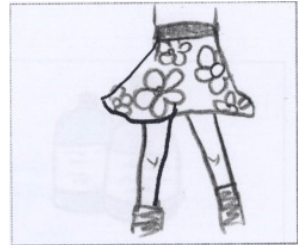

A girl's skirt and legs

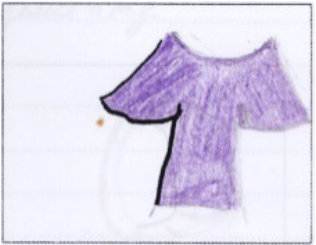

A seater

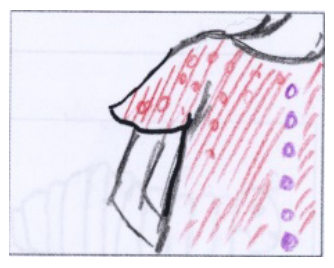

A summer dress

Figure 21. The creative task: interpretation of Fragment 3 - textile items (source: testingmom.com, 2020)

The difference between the processes of association and interpretation is disclosed in using textile items referring to the fragment in question (Table 6): $2.6 \%$ of cases in the process of associations and $17.4 \%$ in that of interpretation. As many as one third (32.3\%) of Belarusian students used the motif of textile items in the creative task: T-shirts, a skirt, a dress, a sweater, etc., $16.1 \%$ of Latvian students drew "a dotted dress", "a rain coat", etc. A third-year 31-year old student from Lithuania related textile items to the fashion industry and in "presenting a new clothes collection on a manikin" (Figure 21).

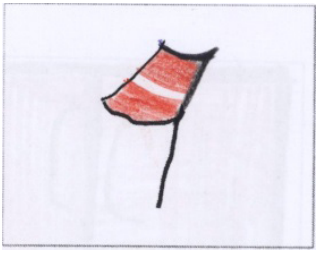

The national flag of Latvia

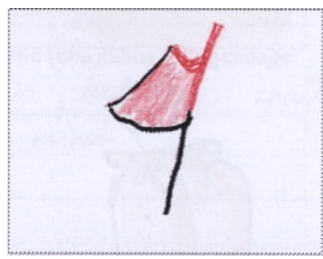

A flag

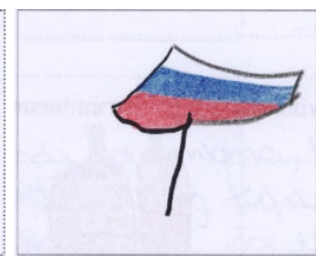

The national flag of Slovenia

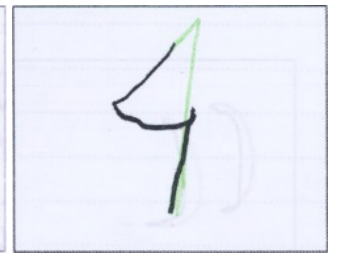

A flag

Figure 22. The creative task: interpretation of Fragment 3 - flags (source: testingmom.com, 2020) 
The research was conducted in five countries but only the research participants from four countries presented flags in their creative task. A first-year Latvian student drew the Latvian national flag, a fourth-year Slovenian student - the Slovenian national flag, a second-year Estonian student - a red flag and a second-year Belarusian student visualised a white flag (Figure 22). The manifestations of patriotism, which are formed in the living environment of an individual, can be seen only in the creative works of Latvian and Slovenian students. It can be stated that the environment of Lithuanian, Estonian and Belarusian students contains too few factors that promote their national identity. The reference to the flag was identified only in the process of interpretation.

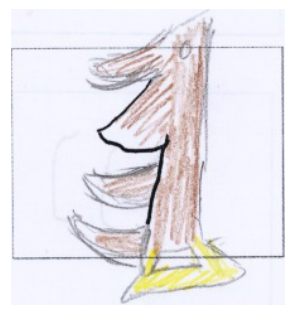

A saw

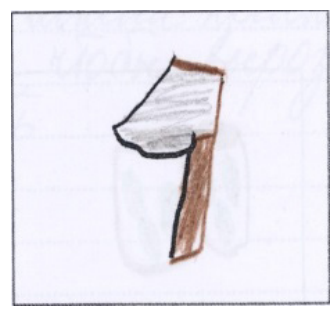

An axe

Figure 23. The creative task: interpretation of Fragment 3 - working tools (source: testingmom.com, 2020)

The associations of Fragment 3 were related to working tools (a saw) by only one 22year old first-year student from Latvia and in the process of interpretation this motif was identified twice. A group of interpreters who envisaged working tools was supplemented by a first-year student of Russian origin from Latvia, who linked the presented fragment with the nose in the process of association and drew a working tool (an axe) in the process of interpretation (Figure 23).

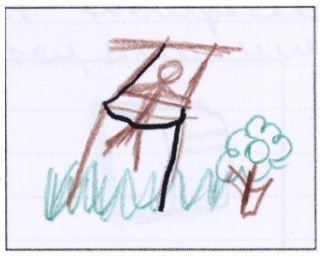

A swing

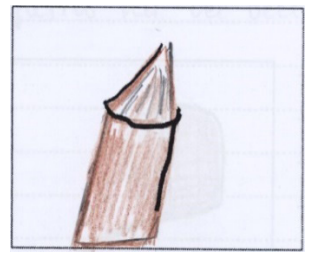

A pencil

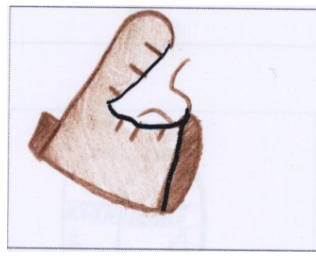

An upside down shoe

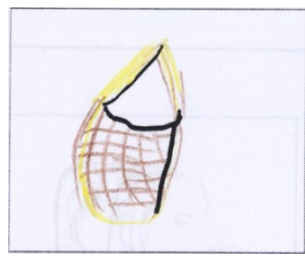

An interwoven basket

Figure 24. The creative task: interpretation of Fragment 3 - exceptional images (source: testingmom.com, 2020)

The images associated with the presented fragment were divided into 9 groups and those of the process of interpretation split into 16 groups. Four exceptional images were identified in both processes. Only once was Fragment 3 related to the already mentioned working tools, umbrellas, animals and games in the process of association (Table 5). In the process of the interpretation the following objects were mentioned for the first time: a stationery item - a pencil, a show, a bag and a swing (Table 6, Figure 24). The authors of these exceptional images were 17-21-year old students from Lithuania and Belarus. 


\section{Analysis of the creative task: Fragment 4}

A combination of line and curve evoked associations with Earth surface deformations, animal images rose from unfinished springs or unfinished symbols of infinity. An irregular letter $\mathrm{M}$ was understood almost as a finished message and evoked the image of earth deformations more frequently and they were more concrete: the mountains were mentioned by research participants in the processes of association and interpretation.

About three fifths of participants associated Fragment 4 of the creative task with mountains. In the process of interpretation, the latter association was translated into mountains by more than half of the students (Tables 7, 8; Figure 25).

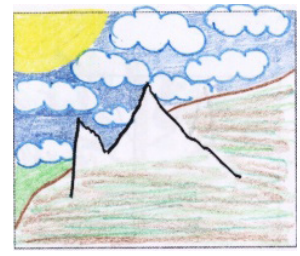

A landscape somewhere in the Himalayas

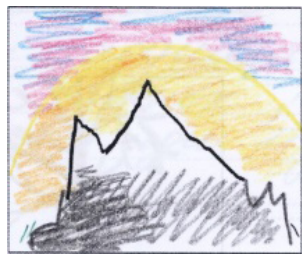

A sunrise in the mountain

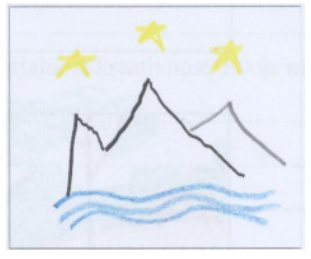

Triglav in the Slovenian coat of arms

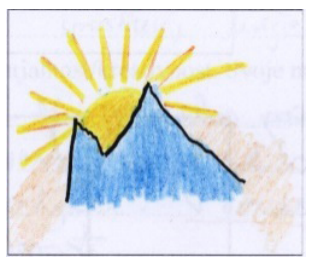

A sunrise

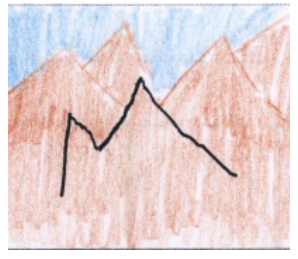

The mountains, Everest

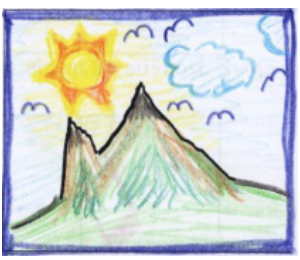

A picture of mountains

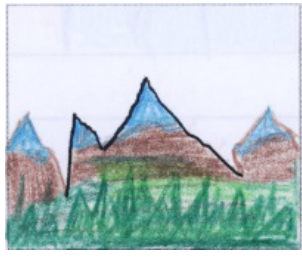

The mountains and firtrees at their foot

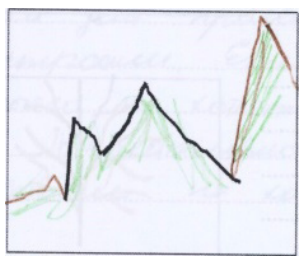

Mountains

Figure 25. The creative task: interpretation of Fragment 4 - mountains (source: testingmom.com, 2020)

Almost all the Slovenian students (94.7\%) linked the presented fragment with mountains in the process of associations, whereas in the process of interpretation the frequency of the motif of mountains decreased by one third (63.2\%). The students from Belarus, a country without mountains in its territory, demonstrated the opposite results: $38.7 \%$ of students initially associated the fragment with mountains, whereas $54.8 \%$ of them used the motif of mountains while interpreting the fragment (Tables 7,8). This fact allows us to conclude that physical environment can affect the process of association just as that of interpretation. However, natural physical environment (nature, buildings, etc.) tends to influence the process of association more, whereas intellectual works (pictures, photos, books, etc.) in the individual's physical environment have considerably more influence in the process of interpretation. 
Table 7. Associations of Fragment 4 (\%) (source: created by authors)

\begin{tabular}{|l|c|c|c|c|c|c|}
\hline & In total & Lithuania & Latvia & Estonia & Slovenia & Belarus \\
\hline \multicolumn{7}{|c|}{ Most frequent associations } \\
\hline Mountains & 60.9 & 47.4 & 71.0 & 60.0 & 94.7 & 38.7 \\
\hline Letters and numbers & 25.2 & 36.8 & 16.1 & 33.3 & 0 & 38.7 \\
\hline Diagrams & 3.5 & 5.3 & 0 & 0 & 0 & 9.7 \\
\hline Electrocardiograms & 3.5 & 5.3 & 0 & 0 & 0 & 9.7 \\
\hline \multicolumn{7}{|c|}{ Least frequent associations } \\
\hline Glass ware & 0.9 & 0 & 3.2 & 0 & 0 & 0 \\
\hline Crown & 0.9 & 0 & 3.2 & 0 & 0 & 0 \\
\hline Philosophy, communication & 0.9 & 0 & 0 & 6.7 & 0 & 0 \\
\hline Animal life & 0.9 & 5.3 & 0 & 0 & 0 & 0 \\
\hline
\end{tabular}

Table 8. Interpretations of Fragment 4 (\%) (source: created by authors)

\begin{tabular}{|l|c|c|c|c|c|c|}
\hline & In total & Lithuania & Latvia & Estonia & Slovenia & Belarus \\
\hline \multicolumn{7}{|c|}{ Most frequent interpretations } \\
\hline Mountains & 54.8 & 57.9 & 48.4 & 53.3 & 63.2 & 54.8 \\
\hline Crown & 15.7 & 10.5 & 22.6 & 6.7 & 15.8 & 16.1 \\
\hline Animal life & 8.7 & 10.5 & 6.5 & 13.3 & 10.5 & 6.5 \\
\hline \multicolumn{7}{|c|}{ Least frequent interpretations } \\
\hline $\begin{array}{l}\text { Letters and } \\
\text { numbers }\end{array}$ & 0.9 & 0 & 3.2 & 0 & 0 & 0 \\
\hline Lightning & 0.9 & 0 & 3.2 & 0 & 0 & 0 \\
\hline $\begin{array}{l}\text { Philosophy, } \\
\text { communication }\end{array}$ & 0.9 & 0 & 0 & 6.7 & 0 & 0 \\
\hline Plant life & 0.9 & 0 & 3.2 & 0 & 0 & 0 \\
\hline Trajectories & 0.9 & 0 & 0 & 6.7 & 0 & 0 \\
\hline States of water & 0.9 & 0 & 0 & 0 & 5.3 & 0 \\
\hline
\end{tabular}

While drawing mountains a third-year Lithuanian student referred to Mount Everest, a second-year Latvian presented "a landscape somewhere deep in the Himalayas", a final year Estonian student drew the Alps and Triglav - the highest mountain in Slovenia and the highest peak of the Julian Alps, Slovenia - is mentioned by Slovenian students eight times (Figure 25). Triglav is also portrayed in the Slovenian flag. Moreover, the metal Aljaž Tower, Slovenia, was built on the peak of the mountain (a national symbol of Slovenia and territorial unity of the country), which was mentioned by a third-year Slovenian student ("Triglav with Aljaž Tower"). The facts attained allow us to conclude that linking a mountain with Triglav is an expression of national identity. Moreover, the mountain is called "Our Triglav".

The influence of intellectual works in the physical environment on the process of interpretation can be identified through linking of the presented fragment with the crown. In the 21 st century the crown is not a common object in our daily environment. That is why only one fourth-year Latvian student associated the presented fragment with the crown. In the 
creative task of interpretation, the frequency of interpreted crowns grew to $15.7 \%$ (Figure $26)$. It should be noted that almost one fourth of Latvians $(22.6 \%)$ drew a crown in the process of interpretation, whereas only $16.1 \%$ of Belarusians, $15.8 \%$ of Slovenians and only $10.5 \%$ of Lithuanians did the same (Table 8 ).

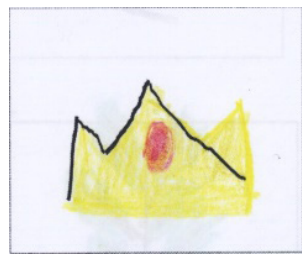

A toy crown

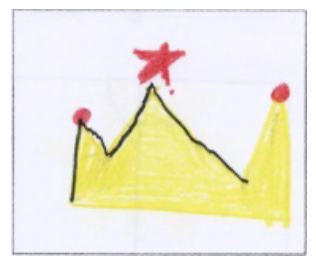

A crown

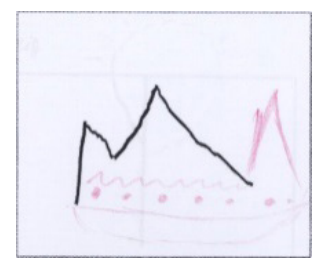

A crown

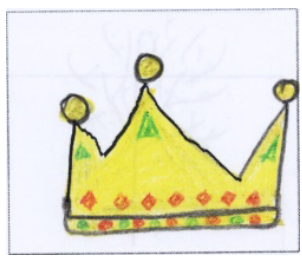

A crown

Figure 26. The creative task: interpretation of Fragment 4 - a crown (source: testingmom.com, 2020)

The influence of physical environment on the process of interpretation can be identified by linking the fragment with animals by the participants (Tables 7,8 ).

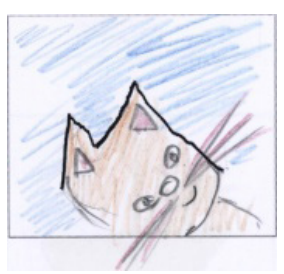

A cat's face

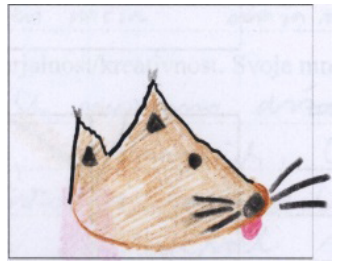

A dog's head

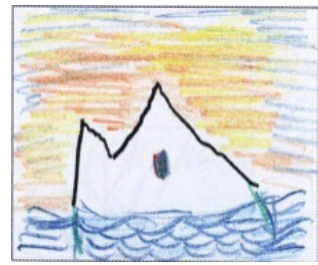

A sigh of fish

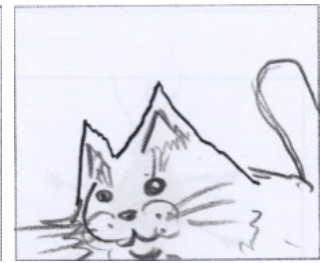

A cat

Figure 27. The creative task: interpretation of Fragment 4 - animals (source: testingmom.com, 2020)

In the process of association only one third-year student from Lithuania envisaged an animal in the given fragment. The number of animals in the process of interpretation grew to $8.7 \%(\mathrm{n}=10)$. Out of 10 animals there were 4 cats, 2 dogs, 2 fish, 1 fox and a shark (Figure 27).

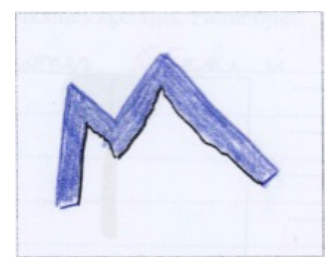

Letter M

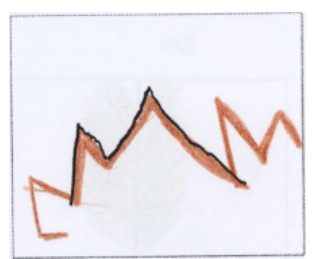

A lightning

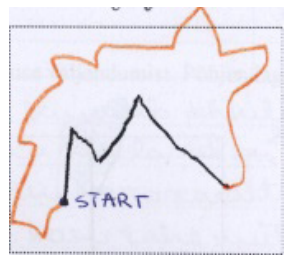

A skiing route

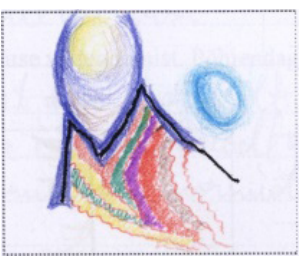

Something beautiful

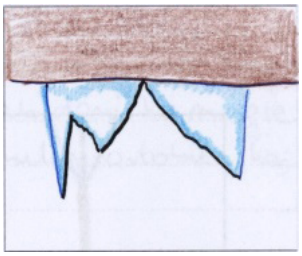

Hanging icicles

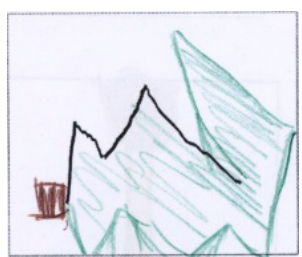

A broken fir-tree

Figure 28. The creative task: interpretation of Fragment 4 - exceptional images

(source: testingmom.com, 2020) 
The associated images of Fragment 4 in the creative task were divided into 9 groups and the images received during the process of interpretation were classified into 15 groups. The group of glassware disappeared after the process of interpretation, but new groups of meadows, plants, human beings, textile items, trajectories and states of water were identified. In the process of association, 4 groups of exceptional images were identified, whereas in the process of interpretation there were 6 such groups (Tables 7, 8; Figure 28). One fourth of the students in the process of association related the given fragment with letters or numbers, whereas in the process of interpretation, the fragment was linked to the letter $\mathrm{M}$ by one second-year student from Latvia.

\section{The analysis of the creative task: Fragment 5}

The images of Fragment 5 of the creative task were divided into 11 groups. The largest number of images was assigned to the group of humans (33.0\%), letters and numbers $(22.6 \%)$ and plant life (11.3\%) (Table 9). Almost half of the Estonian students (46.7\%) linked the presented fragment with a human being, whereas none of the Estonians interpreted the fragment employing the motif of a human. The frequency of linking the presented fragment with a human in the process of interpretation rose among students from other countries (Tables 9, 10): from $31.6 \%$ to $57.9 \%$ among the works of Lithuanian students, from $38.7 \%$ to $54.8 \%$ among those of Latvian students, from $25.8 \%$ to $48.4 \%$ - Belarusian and from $26.3 \%$ to $31.6 \%$ among Slovenians.

The research participants most frequently draw a human similar to young children arms, legs and the body are presented in thin lines and a circle represents the head. The human in the picture of one Lithuanian participant, one Latvian and one Belarusian is sitting sideways. Two Lithuanian students drew a human with balloons, 2 Slovenian and 1 Belarusian student interpreted a human in a full body not using thin lines, 1 Latvian student presented an interpretation of a person "before shooting him", 1 Lithuanian student drew only an ear (Figure 29). It should be noted that the interpretations of Fragment 5 presented by Lithuanian participants can de distinguished by the variety of visualisations of the human body.

Table 9. Associations of Fragment 5 (\%) (source: created by authors)

\begin{tabular}{|l|c|c|c|c|c|c|}
\hline & In total & Lithuania & Latvia & Estonia & Slovenia & Belarus \\
\hline \multicolumn{7}{|c|}{ Most frequent associations } \\
\hline $\begin{array}{l}\text { Human, its body } \\
\text { parts }\end{array}$ & 33.0 & 31.6 & 38.7 & 46.7 & 26.3 & 25.8 \\
\hline $\begin{array}{l}\text { Letters and } \\
\text { numbers }\end{array}$ & 22.6 & 26.3 & 22.6 & 20.0 & 15.8 & 25.8 \\
\hline Plant life & 11.3 & 10.5 & 12.9 & 6.7 & 10.5 & 12.9 \\
\hline \multicolumn{7}{|c|}{ Least frequent associations } \\
\hline Ornamentation & 0.9 & 0 & 3.2 & 0 & 0 & 0 \\
\hline Textile & 0.9 & 0 & 0 & 6.7 & 0 & 0 \\
\hline
\end{tabular}


Table 10. Interpretations of Fragment 5 (\%) (source: created by authors)

\begin{tabular}{|l|c|c|c|c|c|c|}
\hline & In total & Lithuania & Latvia & Estonia & Slovenia & Belarus \\
\hline \multicolumn{7}{|c|}{ Most frequent interpretations } \\
\hline $\begin{array}{l}\text { Human, its body } \\
\text { parts }\end{array}$ & 42.6 & 57.9 & 54.8 & 0 & 31.6 & 48.4 \\
\hline Plant life & 13.9 & 10.5 & 16.1 & 6.7 & 15.8 & 12.9 \\
\hline Character & 7.0 & 5.3 & 6.5 & 20.0 & 10.5 & 0 \\
\hline \multicolumn{7}{|c|}{ Least frequent interpretations } \\
\hline Ornaments & 0.9 & 5.3 & 0 & 0 & 0 & 0 \\
\hline Means of transport & 0.9 & 5.3 & 0 & 0 & 0 & 0 \\
\hline Reading materials & 0.9 & 0 & 3.2 & 0 & 0 & 0 \\
\hline Military attributes & 0.9 & 0 & 3.2 & 0 & 0 & 0 \\
\hline Furniture & 0.9 & 0 & 0 & 0 & 5.3 & 0 \\
\hline Stationery & 0.9 & 0 & 0 & 0 & 0 & 3.2 \\
\hline
\end{tabular}

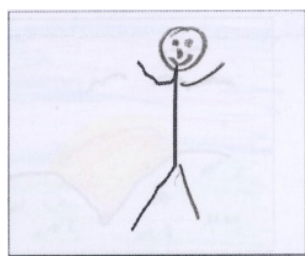

A small man

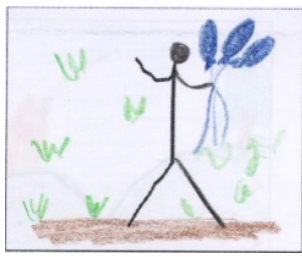

A small man going to congratulate a friend

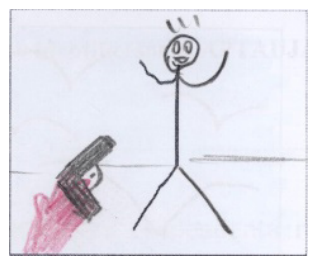

A man before shooting

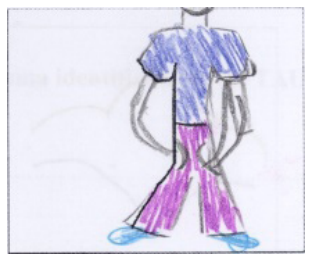

A human

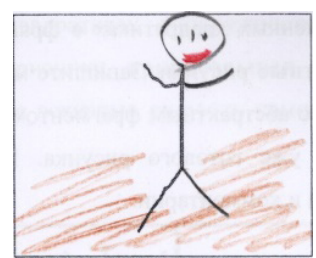

A small man

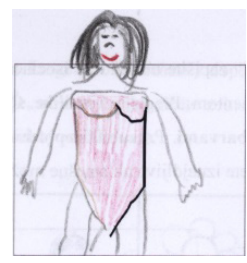

A full-length woman in bikini

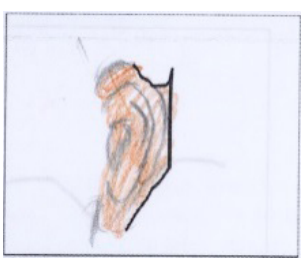

An ear

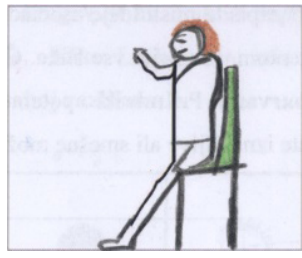

A human sitting on a chair

Figure 29. The creative task: interpretation of Fragment 5 - human being (source: testingmom.com 2020)

A similar quantitative trend was identified in the processes of associating and interpreting Fragment 5 in reference to plans: $11.3 \%(n=13)$ and $13.9 \%(n=15)$ respectively (Tables 9 , 10). The comparison of interpretations of Fragment 5 provided by all participants revealed that Estonians students comprised the smallest group (6.7\%) who interpreted this fragment employing the image of a plant. Trees made up the majority among the interpreted plants: "a birch with roots", "a blossoming apple tree" (Lithuania) or just "a tree" (Latvia, Estonia, Belarus, Slovenia), or "an apple tree" (Slovenia), or even "a broken tree" (Slovenia) (Figure 30). 


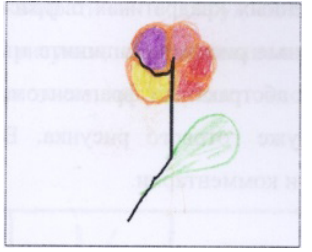

A flower

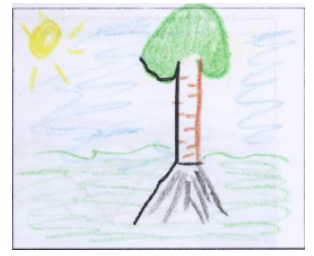

A birch tree with roots

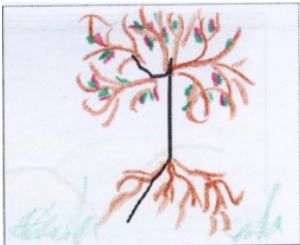

An apple tree in blossom

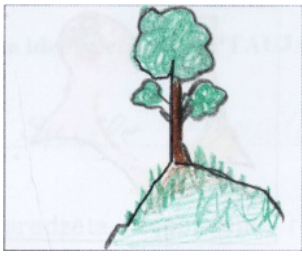

A tree growing on a hill

Figure 30. The creative task: interpretation of Fragment 5 - plants (source: testingmom.com, 2020)

One Latvian student and Belarusian students interpreted not separate plants but a whole landscape: "a park", “[...] see, tree and meadow”, "a landscape" (Figure 31). The research participants from Belarus interpreted the given fragment as a flower or a branch (Figure 30).

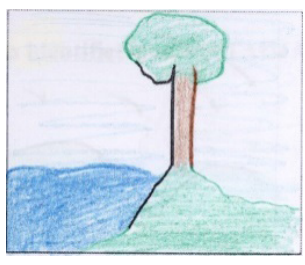

A landscape: a sea, a tree and meadow

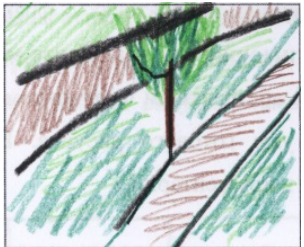

A park

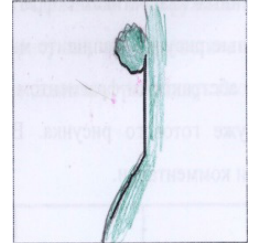

A landscape

Figure 31. The creative task: interpretation of Fragment 5 - landscape (source: testingmom.com, 2020)

The third biggest group of interpretation images of Fragment 5 consists of characters (Table 10, Figure 32): “a fabulous bird” (Lithuania), "an alien”, “a king” (Latvia), "kapsu-juku”, "a ballet dancer", "little John with head” (Estonia), "a volleyball player", "a dancer" (Slovenia). As many as one fifth (20.0\%) of Estonian participants interpreted the discussed fragment as a character, whereas Belarusian students did not provide the above-mentioned interpretation. It should also be mentioned that the research participants did not provide any characters in the process of associations.

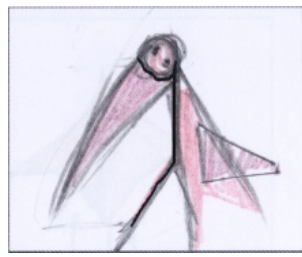

A fabulous bird

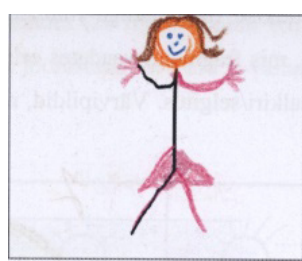

A ballet dancer

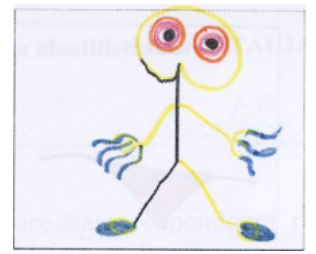

An alien

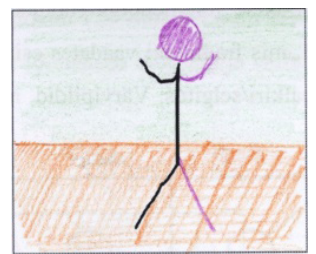

Sitting little John with the head

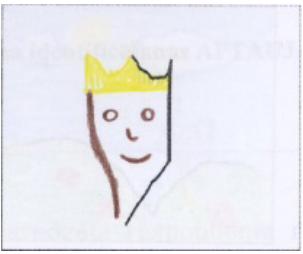

A king

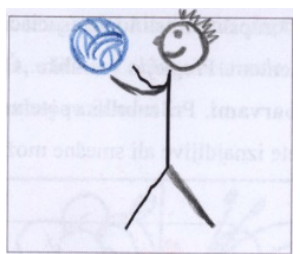

A volleyball player

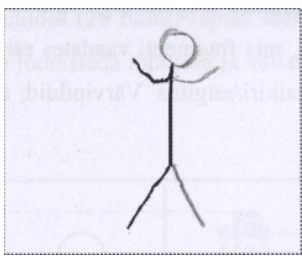

Kupsu-Juku

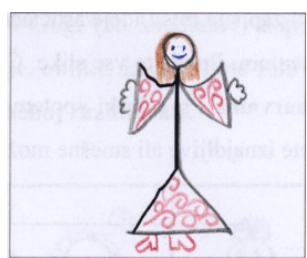

A dancer

Figure 32. The creative task: interpretation of Fragment 5 - a character (source: testingmom.com, 2020) 
For more than one fifth $(22.6 \%)$ of the participants, the presented fragment reminded them of letters and numbers, although only one third-year student from the University of Daugavpils, Latvia, further worked on it in the process of interpretation (Figure 33).

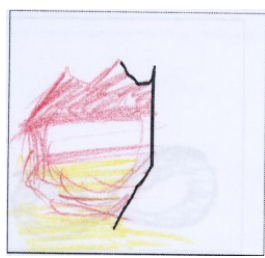

A crown without the owner

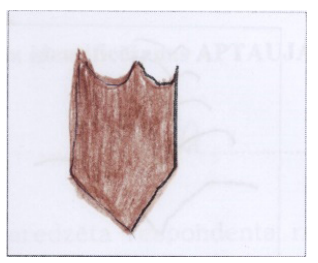

A shield (of warrior)

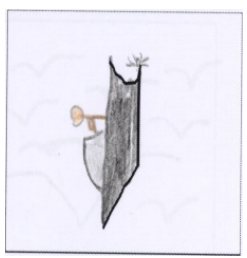

A cutter

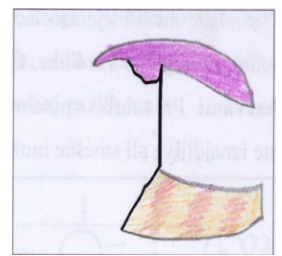

A sunlounge in the beach

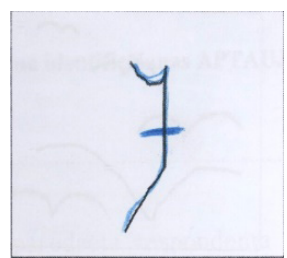

Letter J

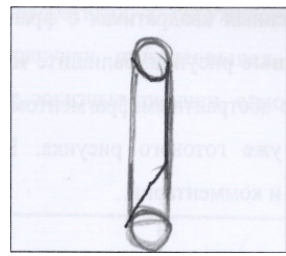

A pencil case,

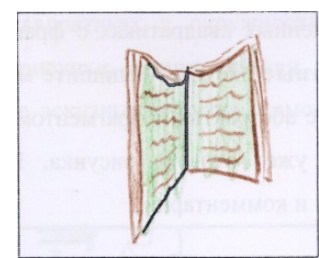

A book

Figure 33. The creative task: interpretation of Fragment 5 - exceptional images (source: testingmom.com, 2020)

The following objects were found among exceptional interpreted images: a cutter as a means of transportation (Lithuania), a book and a warrior's shield (Latvia), a sunlounger with an umbrella (Slovenia) and a stationery item: a pencil tube (Belarus) (Figure 33). Research participants from Estonia did not provide any exceptional interpretations of this fragment.

\section{Presence/absence of the relationship between association and interpretation: "partisan" activity of visual culture}

As previously mentioned, values and identities constructed and passed down by visual culture have an indiscernible impact on the subject, and influence a person without them being aware, particularly if they do not understand visual material and have little or no idea of how perception of visual material is accumulated. This lack of understanding was evident in the many different associations and interpretations made by the participants. It is axiomatic that processes of association and interpretation are complex and frequently independent of each other.

When analysed, the research data leads us to conclude that the process of interpretation has a quantitative advantage over that of association (Table 11). Moreover, the thematic groups of associated images frequently disappeared in the process of interpretation and new topics, which were not envisaged in the process of associations, were created. This shows a misbalance between the processes of receiving and sending surprising), yet the receiver limits themself to elementary associations evoked by the received messages in the process of communication. The sent message is understandable to its sender (which is not message; no efforts are made in order to evoke associations if they do not arise themselves. 
Table 11. Groups of images in the processes of association and interpretation (source: created by authors)

\begin{tabular}{|c|c|c|c|c|c|}
\hline 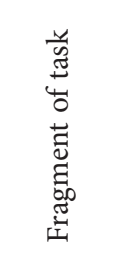 & 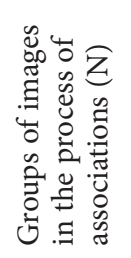 & 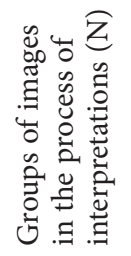 & 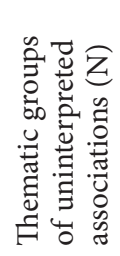 & 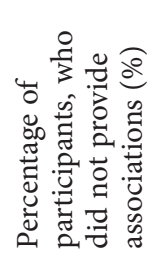 & 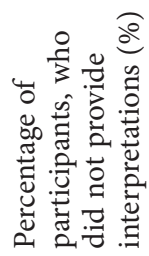 \\
\hline 1 & 16 & 19 & 1 & 4.3 & 2.6 \\
\hline 2 & 15 & 18 & 3 & 1.7 & 0.9 \\
\hline 3 & 9 & 16 & 0 & 1.7 & 0 \\
\hline 4 & 9 & 15 & 1 & 0.9 & 0 \\
\hline 5 & 11 & 18 & 2 & 7.0 & 0 \\
\hline Average & 12 & 17.2 & 1.4 & 3.1 & 0.7 \\
\hline
\end{tabular}

Analysis of the research data shows that four times more participants were unable to identify an association compared to those who presented interpretations (Table 11). Thus, an active interpretation process is more acceptable and attractive to the research participants than the passive creation of associations. There is a tendency for the viewer to avoid making much effort to understand content; they would rather construct content of their own, which is much easier than looking for meanings of received content. This shows that skills required to understand abstract contents are poorer compared to those of content creation. Moreover, abstract content evokes associations less frequently than interpretations, and the created contents-interpretations are concrete. In general, there is a disposition to the interpretation of content rather than to its understanding, which may reflect curriculum and teaching processes in respective educational systems. Broadly, the latter considers understanding as a necessary prerequisite for interpretation but is not deliberately formed and left as a component of interpretation.

\section{Conclusions}

Associations and interpretations allow for the expression of visual culture. The convergence of content formed in the context of global media content does not result in the unification of associations and interpretations evoked by this content, which in turn localizes and links meanings of content with local culture. The processes of association and interpretation are influenced by animate and non-animate environments and objects created by nature and humans, fairy-tale characters, as well as a variety of activities. The most common images that emerged during the above-mentioned processes are the usual objects or images that represent them. In associations, images of the physical environment are more frequently provided, whereas interpretation more frequently refers to intellectual creations (e.g. means of transportation, buildings, textile goods, etc.). In the process of association, the research participants most frequently use what they routinely see, what is usual for them and does not cause any surprise. It would appear that in the process of interpretation the participants 
create what they do not have (features: exceptionality, uniqueness, unavailability in the territory or environment), or what is exceptionally important, close, dear or significant to them. However, to disclose more comprehensive sources of images arising from these experiments additional research is needed.

National associations and interpretations are more characteristic of the countries, where national elements are more frequently visible in the direct environment. For example, the works of students from Latvia and Slovenia contained more images reflecting national identity. In the environment of the participants from countries represented in the experiment there is an abundance of factors promoting national identity, which is not typical of other countries in the research.

Single objects are more easily distinguished and expressed in the flow of communication. We noticed that separate objects are more frequently represented in the process of interpretation compared to an overall image. Sexuality in the associations and interpretations of images was not related to a specific group - the portrayal of body of the same or opposite sex was not typical of a specific gender, age, nationality or country.

The relation with visual culture frequently is not reflexive. The processes of association and interpretation are unstable and often independent of each other. Associations that are made do not necessarily grow into interpretations, although the process of interpretation is quantitatively superior than the process of association. The perception and implementation of images of the environment make for a more continuous process compared to images of intellectual creation - images of the physical environment more frequently grow into the process of interpretation than images of intellectual creation (e.g. numbers). This also reflects the curriculum of education systems - the study subjects of language, literature and the arts encourage reading (observation, listening to) descriptions of landscapes and townscapes and their analysis and interpretation. Working tools also have to be used or designed according to presented models, numbers, especially in mathematical operations without particular consideration of them.

The relative position of receiver and sender in the communication process is revealed through their relationship with content - refusal to interpret. A strongly expressed focus on single objects reveals a lack of reflection in perceiving visual contents of communication and avoidance to communicate through complex and abstract images, which also shows insufficient reflection when constructing a communicative message.

\section{References}

Adler, A. (2014). The practice and theory of individual psychology. Series: The International Library of Psychology. Routledge.

Adler, A. (2011). The science of living. Routledge.

Basadur, M., \& Hausdorf, P. A. (1996). Measuring divergent thinking attitudes related to creative problem solving and innovation management. Creativity Research Journal, 9(1), 21-32. https://doi.org/10.1207/s15326934crj0901_3

Beaty, R. E., Christensen, A. P., Benedek, M., Silvia, P. J., \& Schacter, D. L. (2017). Creative constraints: brain activity and network dynamics underlying semantic interference during idea production. NeuroImage, 148, 189-196. https://doi.org/10.1016/j.neuroimage.2017.01.012 
Clapham, M. M. (2004). The convergent validity of the torrance tests of creative thinking and creativity interest inventories. Educational and Psychological Measurement, 64(5), 828-841. https://doi.org/10.1177/0013164404263883

Cramond, B., Matthews-Morgan, J., Bandalos, D., \& Zuo, L. (2005). A Report on the 40-Year followup of the torrance tests of creative thinking: alive and well in the new millennium. Gifted Child Quarterly, 49(4), 283-291. https://doi.org/10.1177/001698620504900402

Cropley, A. J. (2000). Defining and measuring creativity: are creativity tests worth using? Roeper Review, 23(2), 72-79. https://doi.org/10.1080/02783190009554069

Crozier, W. E., Strange, D., \& Loftus, E. F. (2017). Memory errors in alibi generation: how an alibi can turn against us. Behavioral Sciences and the Law, 35(1), 6-17. https://doi.org/10.1002/bsl.2273

Davachi, L. (2004). The ensemble that plays together, stays together. Hipocampus, 14(1), 1-3. https://doi.org/10.1002/hipo.20004

Davachi, L., Mitchell, J. P., \& Wagner, A. D. (2003). Multiple routes to memory: distinct medial temporal lobe processes build item and source memories. Proceedings of the National Academy of Sciences of the United States of America, 100(4), 2157-2162. https://doi.org/10.1073/pnas.0337195100

Davachi, L., \& Wagner, A. D. (2002). Hippocampal contributions to episodic encoding: insights from relational and item-based learning. Journal of Neurophysiology, 88(2), 982-990. https://doi.org/10.1152/jn.2002.88.2.982

Diener, E., Pressman, S. D., Hunter, J., \& Delgadillo-Chase, D. (2017). If, why, and when subjective wellbeing influences health, and future needed research. Applied Psychology: Health and Well-Being, 9(2), 133-167. https://doi.org/10.1111/aphw.12090

Frenda, S. J., Patihis, L., Loftus, E. F., Lewis, H. C., \& Fenn, K. M. (2014). Sleep deprivation and false memories. Psychological Science, 25(9), 1674-1681. https://doi.org/10.1177/0956797614534694

Furley, Ph., \& Memmert, D. (2015). Creativity and working memory capacity in sports: working memory capacity is not a limiting factor in creative decision making amongst skilled performers. Frontiers in Psychology, 6. https://www.frontiersin.org/articles/10.3389/fpsyg.2015.00115/full

Gilhooly, K. J., Fioratou, E., Anthony, S. H., \& Wynn, V. (2007). Divergent thinking: strategies and executive involvement in generating novel uses for familiar objects. British Journal of Psychology, 98(4), 611-625. https://doi.org/10.1111/j.2044-8295.2007.tb00467.x

Green, D. M., Strange, D., Lindsay, D. S., \& Takarangi, M. K. T. (2016). Trauma-related versus positive involuntary thoughts with and without meta-awareness. Consciousness and Cognition, 46, 163-172. https://doi.org/10.1016/j.concog.2016.09.019

Guilford, J. P. (1950). Creativity. American Psychologist, 5(9), 444-454. https://doi.org/10.1037/h0063487

Guilford, J. P. (1968). Creativity, intelligence, and their educational implications. EDITS/Robert Knapp.

Kim, K. H. (2006). Can we trust creativity tests? A review of the Torrance Tests of Creative Thinking (TTCT). Creativity Research Journal, 18(1), 3-14. https://doi.org/10.1207/s15326934crj1801_2

Kim, K. H. (2011). The APA 2009 division 10 debate: are the torrance tests of creative thinking still relevant in the 21st century? Psychology of Aesthetics, Creativity, and the Arts, 5(4), 302-308. https://doi.org/10.1037/a0021917

Kuykendall, L., Tay, L., \& Ng, V. (2015). Leisure engagement and subjective well-being: a meta-analysis. Psychological Bulletin, 141(2), 364-403. https://doi.org/10.1037/a0038508

Leclerc, R. (2017). Play, think, design: play as a means to acquire and enhance design thinking skills. In K. W. M. Siu, \& G. J. Contreras (Eds.), Design education for fostering creativity and innovation in China (pp. 179-211). Series: Premier Reference Source. IGI Global. https://doi.org/10.4018/978-1-5225-0911-0.ch008

Loftus, E. F. (1997). Creating false memories. Scientific American, 277(3), 70-75. https://doi.org/10.1038/scientificamerican0997-70 
Loftus, E. F., \& Pickrell, J. E. (1995). The formation of false memories. Psychiatric Annals, 25(12), 720-725. https://doi.org/10.3928/0048-5713-19951201-07

Mednick, S. (1962). The associative basis of the creative process. Psychological Review, 69(3), 220-232. https://doi.org/10.1037/h0048850

New World Encyclopedia. (2018). J. P. Guilford. https://www.newworldencyclopedia.org/entry/J._P._ Guilford

Oberauer, K., Süß, H.-M., Wilhelm, O., \& Wittmann, W. W. (2008). Which working memory functions predict intelligence? Intelligence, 36(6), 641-652. https://doi.org/10.1016/j.intell.2008.01.007

Paulus, P. B., \& Brown, V. R. (2007). Toward more creative and innovative group idea generation: a cognitive-social-motivational perspective of brainstorming. Social and Personality Psychology Compass, 1(1), 248-265. https://doi.org/10.1111/j.1751-9004.2007.00006.x

Piaget, J. (2001). The psychology of intelligence. Routledge.

Piaget, J., \& Inhelder, B. (1996). The psychology of the child. Basic Books, Inc.

Puryear, J. S., Kettler, T., \& Rinn, A. N. (2017). Relationships of personality to differential conceptions of creativity: a systematic review. Psychology of Aesthetics, Creativity, and the Arts, 11(1), 59-68. https://doi.org/10.1037/aca0000079

Runco, M. A. (2008). Commentary: divergent thinking is not synonymous with creativity. Psychology of Aesthetics, Creativity, and the Arts, 2(2), 93-96. https://doi.org/10.1037/1931-3896.2.2.93

Russ, S. W., \& Dillon, J. A. (2011). Associative theory. In M. A. Runco \& S. R. Pritzker (Eds.-in-Chief). Encyclopedia of creativity (pp. 66-71). Elsevier Inc. https://doi.org/10.1016/B978-0-12-375038-9.00014-5

Seligman, M. E. P., \& Csikszentmihalyi, M. (2000). Positive psychology: an introduction. American Psychologist, 55(1), 5-14. https://doi.org/10.1037/0003-066X.55.1.5

Smeekens, B. A., \& Kane, M. J. (2016). Working memory capacity, mind wandering, and creative cognition: an individual-differences investigation into the benefits of controlled versus spontaneous thought. Psychology of Aesthetics, Creativity, and the Arts, 10(4), 389-415. https://doi.org/10.1037/aca0000046

Spartano, N. L., Himali, J. J., Beiser, A. S., Lewis, G. D., DeCarli, Ch., Vasan, R. S., \& Seshadri, S. (2016). Midlife exercise blood pressure, heart rate, and fitness relate to brain volume 2 decades later. Neurology, 86(14), 1313-1319. https://doi.org/10.1212/WNL.0000000000002415

Sun, M., Wang, M., \& Wegerif, R. (2019). Using computer-based cognitive mapping to improve students' divergent thinking for creativity development. British Journal of Educational Technology, 50(5), 2217-2233. https://doi.org/10.1111/bjet.12825

Süß, H.-M., Oberauer, K., Wittmann, W. W., Wilhelm, O., \& Schulze, R. (2002). Working-memory capacity explains reasoning ability - and a little bit more. Intelligence, 30(3), 261-288. https://doi.org/10.1016/S0160-2896(01)00100-3

TestingMom.com. (2020). Sample Torrance Questions. https://www.testingmom.com/tests/torrance-test/ sample-torrance-practice-questions/

Tharp, T., \& Reiter, M. (2006). The creative habit: learn it and use it for life. A practical guide. Simon \& Schuster Paperbacks.

Torrance, E. P. (1974). Torrance Tests of creative thinking: norms-technical manual. Scholastic Testing Service.

Torrance, E. P. (1995). Why fly? A philosophy of creativity. Ablex Publishing Corporation.

Vartanian, O., Jobidon, M.-E., Bouak, F., Nakashima, A., Smith, I., Lam, Q., \& Cheung, B. (2013). Working memory training is associated with lower prefrontal cortex activation in a divergent thinking task. Neuroscience, 236, 186-194. https://doi.org/10.1016/j.neuroscience.2012.12.060 
Vygotsky, L. S. (1979). Mind in society: the development of higher psychological processes. M. Cole, V. John-Steiner, S. Scribner, \& E. Souberman (Eds.). Harvard University Press. https://doi.org/10.2307/j.ctvjf9vz4

Zmigrod, Sh., Colzato, L. S., \& Hommel, B. (2015). Stimulating creativity: modulation of convergent and divergent thinking by transcranial Direct Current Stimulation (tDCS). Creativity Research Journal, 27(4), 353-360. https://doi.org/10.1080/10400419.2015.1087280

\title{
KULTŪRIŠKAI FORMUOJAMA VIZUALINE KOMUNIKACIJA KÜRYBINĖJE EKSPRESIJOJE
}

\author{
Ilona VALANTINAITÉ, Živilè SEDEREVIČIŪTĖ-PAČIAUSKIENĖ, \\ Viktorija ŽILINSKAITÉ-VYTÉ
}

\begin{abstract}
Santrauka
Žmogaus kūnas ir sąmonė sąveikauja su daugybe išorinių ir vidinių veiksnių, įskaitant, be kitų, supančią aplinką, išgyventas emocijas, išvystus dalykus, dalykus, kurie yra turimi ir liečiami, bei juntamą prisirišimą - visa tai kaupiasi kaip asmeninė patirtis. Minètame procese atmintis atlieka paț svarbiausią vaidmenị ir iš anksto nulemia tai, kiek individas prisimena (ir suvokia) savo paties patirti, bei tai, kaip jis identifikuoja ir supranta savo paties savigarbą ir t. t. Šio tyrimo tikslas - užfiksuoti idejją ir jos transformacijas, atsižvelgiant ị asociacijas, realizavimą ir interpretacijas, susijusias su ja. Tad transformacijos reikalauja asmeninès patirties, atminties, žinių, verbalinių ir neverbalinių gebejimų, taip pat psichinių reiškinių, i̇vykstančių tyrimo metu sąveikaujant jo dalyviams. Mūsų tyrimo užduotyje pristatėme penkis ketvirtainius, kuriuose buvo pateikti abstrakčių paveikslèlių fragmentai. Dalyvių buvo paprašyta laisvai interpretuoti fragmentus ir užbaigti paveikslèlius piešti. Gauti rezultatai leido padaryti išvadą, kad asociacijos ir interpretacijos procesas(-ai) nuolat kinta ir nepriklauso vienas nuo kito. Paprastai asociacijos vizualizuoja požiūrius $\mathfrak{i}$ mūsų fizinę aplinką, o intelektinè kūryba dažniausiai reiškiasi interpretacijose.
\end{abstract}

Reikšminiai žodžiai: vizualinè komunikacija, asociacijos, kūrybiškumas, divergentinis mąstymas, interpretacijos. 